\title{
DEPOPULATING SEMI- PERIPHERY? LONGER TERM DYNAMICS OF MIGRATION AND SOCIOECONOMIC DEVELOPMENT IN ROMANIA
}

\section{István Horváth - Tamás Kiss}

\begin{abstract}
Romania is among Eastern European societies facing a massive depopulation in the last two and a half decades. Large-scale emigration has occurred under the circumstances of massive fertility decline and population ageing following 1989. Immigration has been insignificant until now, in spite of the negative natural growth and the presence of large Romanian-speaking populations next to the Eastern borders of the country. Our paper investigates long-term migratory trends and their relation to general macro-economic and macro-social processes. We place the Romanian historical experience concerning developmental aspects of changes in migratory flows and stocks. Existing macro-historical narratives diverge first in their expectations concerning socioeconomic development. On the one hand, models of "migration transition" and "migration cycles" share an optimistic view of developmental prospects of peripheral and semi-peripheral societies. For instance, Skeldon considered the Eastern European region as an "emerging or potential core". As a consequence, he expected that these societies would become new destinations of global migratory flows. On the other hand, researchers relying on world-system theory emphasize that global structural inequalities are likely to persist, thus Eastern European societies are likely to remain enclosed in their semi-peripheral condition. Under such circumstances massive emigration could continue and could lead to large-scale depopulation of certain regions. Our paper argues that the long-term evolution of macro-structural indicators and migratory flows in Romania do not substantiate developmental optimism. World-system theories could provide useful frame to interpret existing data.
\end{abstract}


Keywords: World-system theory, migration history, Romania, migration and development

István Horváth

Romanian Institute for Research on National Minorities, Cluj, Romania

E-mail: ihorvath66@yahoo.com

Tamás Kiss

Romanian Institute for Research on National Minorities, Cluj, Romania E-mail: t_kiss77@hotmail.com

\section{INTRODUCTION}

Our case study provides an outline of the historical trends of international migration and macro-level societal change in Romania in the time period between 1950 and 2011.' Comparative studies seeking to identify converging elements of the long-term migratory processes in the South-Eastern European region revealed some regional transnational convergence, but also found major divergences of the migratory trends (Melegh, 2012; Fassmann et al., 2014).

The Romanian case study could be useful in highlighting the historical interrelation between socioeconomic change (development) and transnational migration. Our paper not only describes these processes and tries to show the relationship between them, but also aims to place the Romanian experience into relevant theoretical frameworks concerning long-term trends of migration and development. It argues that world-system theory is particularly insightful in interpreting this case.

Our paper will be organized into four parts. The first part reviews the theoretical considerations regarding developmental and demographic drivers of migration. As mentioned already, we will rely primarily on world-system and dependency theories. We will shortly outline models of migratory transition too Developmental optimism and the expectation that all European countries will become countries of immigration are quite widespread. In fact, we will formulate our arguments against these expectations. That was why we considered it

\footnotetext{
'The case study is a revised version of a country report elaborated in the framework of the SEEMIG project (Horváth and Kiss, 2013). Similar long-term historical analyses were carried out for other countries of the North-Western part of the South-East European region, namely Austria, Bulgaria, Hungary, Italy, Serbia, Slovenia and Slovakia.
} 
important to sketch some of the major presumptions of the model of migratory transition. The next two parts are primarily descriptive. They present the evolution of major economic and social processes, and the trends of transnational migration. The final chapter not only summarizes our main conclusions, but also refers back to the theoretical part and interprets the Romanian case in the framework of the world-system theory.

\section{DEVELOPMENT AND MIGRATION - THEORETICAL PARADIGMS}

Scholars engaged in revealing regularities in long-term trends of migration often emphasize the scarcity of general theoretical models. However, they also admit that such generalizations exist and profoundly shape expectations and policies concerning migration (de Haas, 2010; Melegh, 2012). It is also worth mentioning that generalizations concerning long-term migratory processes are deeply rooted in presumptions (or ideologies) concerning societal change, or "development" (de Haas 2010; 2012).

Two major lines of theorizing relation between migration and development can be identified: the first set of theories comprise migration within a universal, more or less linear course of economic development, the second line of thought sees migration as result of the enduring structured inequalities of the global economy.

On the one hand, the universalistic developmental paradigm sees long-term migratory dynamic as a result of universally expanding development. As neoclassical theory of migration postulates (Todaro, 1969; Todaro and Maruszko, 1987; Borjas, 1989), migration is engendered by existing wage differentials. As a counteraction to workers' mobility to high income countries, capital tend to relocate to societies with lower cost of labor, eventually instituting a functional equilibrium (de Haas 2010, p.5), leading to more optimal allocation of labor force and thus to price equalization and the convergence of wages (and more generally developmental trajectories). Models of mobility or migration transition (Zelinsky, 1971; Skeldon, 1997; 2012) are deeply embedded in the evolutionist theories of modernization, like Rostow's (1960) theory of economic growth, or Notestein's idea of demographic transition (Notestein, 1945; see also Melegh, 2006, pp.71-76). Consequently, they predict for different areas of the world a convergence of the dynamically changing migratory patterns, the only difference being the historical period when different phases of particular migratory courses occur. Zelinsky (1971, p.222) stated this aspect explicitly in relation with its spatial mobility transition model: "there are definite, patterned regularities in growth of personal mobility 
[...], and these regularities comprise an essential component of modernization processes". The model of "migration cycles" is also a variant of migration transition theories, combined with the neo-classical expectations concerning migrants' behavior. The model refers to European core, to potential core countries, and it is "based on the assumption that all European nations states develop from emigration into immigration countries" (Fassmann and Reeger, 2012, p.5). Similarly to Zelinsky's model, the importance of demographic evolution is emphasized. European countries experience continuously low rates of fertility, negative natural growth and population ageing. As a consequence, there is an acute shortage of labor force, first of all (but not exclusively) in the secondary sector of the labor market. Under such circumstances, neither economic growth nor the welfare system could be sustained without a significant influx of migrants. Fassmann's and Reeger's innovation was that they emphasized the central role of migration policy regimes. They argued that advanced societies should go through certain phases of adaptation and should develop mechanisms to face the consequences of the aforementioned demographic evolution. This adaptation leads first to legal and institutional changes. European countries redefine their migration policies, citizenship policies represent a more inclusive and seldom reformulated immigration policy, a public opinion accepting immigration and of course high levels of inflows. We should note that from this perspective East European societies (labeled as "potential core" by Skeldon), facing the same demographic challenges, are "not-yet-immigration countries" (Fassmann, Musil and Gruber, 2013, p.25).

On the other hand, world-system and dependency theories differ sharply in their assumptions concerning the possibilities of peripheral and semi-peripheral societies to grow in a manner to reduce the development gap. From this perspective, power asymmetries and economic inequalities between different regions are enduring and likely to persist. According to this paradigm the outflow of capital from the core regions and the diffusion of economic activities toward peripheries is undoubtedly an ongoing process, but in parallel a constant spatial "concertation in control, ownership and profit appropriation" takes place (Sassen, 2005, p.33). Under these circumstances, the global economic growth barely results in the reduction of economic gaps, but is merely conducting to increasing returns for the core regions.

Subsequently migration is not just a consequence of these structural inequalities, but works as a mechanism through which the core reproduces the asymmetric relations with peripheries. As Portes and Böröcz (1989, p.608) argued, prior contacts between sending and receiving societies in generating migratory flows are very important factors. Migration is most likely to emerge 
between former colonies and colonizers. When such prior connections are lacking, active state involvement stimulates the engendering of migratory flows, as was the case of West German "Gastarbeiter" flow (Portes and Böröcz, 1989, p.609). They emphasize that in any case migratory flows are preceded by various forms of penetration of the institutional structures of the stronger states into those of the weaker societies, states.

Portes and Böröcz (1989, p.607) highlighted that parallel to institutional penetration a cultural penetration occurs too. They emphasized that patterns of consumption of the advanced center are diffused throughout the sending society. In this sense Fehérváry's (2002) paper is illustrative. She drew our attention to that as far as consumer aspirations are concerned, in Hungary the reference group was the middle class of Western countries in the 1990s. This also means (and is connected to the fact) that strategies of social mobility and reproduction are no more enclosed within national societies but are increasingly organized on a global hierarchical social space - called "East-West slope" by Melegh (2006). The increasing awareness of developmental hierarchies could also be perceived as a consequence of cultural penetration. The notion of developmental idealism elaborated by Thornton (2005) could also be used in a world-system framework. The acceptance of developmental hierarchies, putting Western societies at the pinnacle of the developmental process is in fact a key element of developmental idealism. Melegh (2012) also highlighted that - next to "Western" consumption aspirations - stringer belief in developmental idealism and "awareness" of developmental hierarchies could be also direct drivers conducting to higher rates of out-migration. This is not necessarily a contrary but rather a complementary argument to neo-classical assumption of wage-maximizing migrants.

According to Böröcz (2015), world-system theory is particularly relevant when analyzing the former Soviet Bloc countries. He sees socialism as an attempt to isolate Eastern European societies from the structure of global economy and core-periphery logic (Böröcz, 2015, pp.6-7). Socialist states not only controlled economies, but attempted to regulate various demographic processes too, including internal and transnational flows of migration. ${ }^{2}$ The collapse of these regimes could be perceived as the abolition of state control over these processes, thus starting with the 1990s these societies and populations returned "to that part of global productive assets of humankind that is valorized by global capital without the interference of the socialist state" (Böröcz, 2015, p.21). However,

\footnotetext{
${ }^{2}$ Leading Romanian social scientists of that time also emphasized the importance of state control over demographic development (Trebici, 1978) and flows of internal migration (Sandu, 1984).
} 
this historical restoration was barely triumphant. The incumbent structural adjustments resulted in a severe economic decline, restating the semi-peripheral, peripheral positions, specific to these states before World War II.

In what follows we describe first relevant macro-economic trends in Romania in the period between 1950 and 2011. We will focus primarily on the evolution of Romania's relative economic position. The evolution of GDP per capita compared to world average and to Western European core countries is indicative in this sense. The structure of the Romanian economy is also informative. The loss of previous industries, the presence or the re-occurrence of larger agrarian populations could also be important in larger scale emigration (Melegh, 2011). The survival of a large agrarian economic sector and the importance of lowvalue added industrial sectors also confirm Böröcz's (2015) thesis that the country has been reintegrated in a (semi-)peripheral position in the global economy. Second, we distinguish several waves of out-migration focusing on changing regimes of international migration. Third, we analyze the trend of outmigration, emphasizing Romania's incapability to attract immigrants, in spite of existing labor-force demand in certain domains and the presence of large Romanian speaking groups next to the country's Eastern borders.

\section{MACRO-ECONOMIC AND SOCIAL TRENDS}

\section{Major macro-economic trends}

Regarding the major macro-economic trends of the period between 1950 and 2011, in addition to the collapse of the state socialism 1989, the late 1970s represent a major turning point of Romania's economic development. Till the 1980s, the Romanian economy grew dynamically, while the relative (global) economic position of the country was considerably improving. In the late 1970s, however, a two-decade-long economic stagnation and downturn began, eventually resulting in the fall of the communist regime.

Before World War II, Romania had a peripheral ${ }^{3}$ position in the global capitalist economy (Stan and Erne, 2013, p.26). After the Communist Party seized power in 1945 and stabilized its rule (in 1947), it initiated a large-scale process of economic restructuration. First of all, it changed the regime of property, following large

${ }^{3}$ Chirot (1976) argued that Romania was incorporated into the emerging global capitalism in a peripheral position during the 19 ${ }^{\text {th }}$ century. According to Berend and Ránki (1982) "Central European" societies (Hungary, Slovakia, Poland, and Czech Republic) had a semi-peripheral position. Romania's lower position on this centrum-periphery relationship has severe consequences on migratory flows too. 
scale expropriations, imposed public ownership on the means of production, and then imposed a centrally coordinated (planned) system of macro-economic management. By 1950, the nationalization in industry was nearly accomplished, and the restructuring of agricultural production (collectivization) commenced too (Kligman and Verdery, 2012). From the 1950s until the second half of the 1970s high level of investments in industry and the redirection of labor force from agriculture toward industrial production were the main drivers of economic growth.

Thus between 1950 and 1955, 24.3\% of the GDP was used for investments, growing to 36\% in the period 1976-1980 (Murgescu, 2010, p.337). In this period of economic restructuring the allocations for industrial investments was the priority. Within the industrial sector particular attention was paid to developing heavy industry (metallurgy, manufacturing of industrial machinery) and chemical industry (particularly oil processing), while the industries with a more consumer oriented production received far less investment. ${ }^{4}$ This also implies that the financing of education or the health care system remained relatively low (compared to other Eastern European states). Though the focus on industrial investments was a general characteristic of Eastern European development strategies, yet such prevailing support for heavy industry as opposed to the branches producing consumer goods was a Romanian idiosyncrasy (Ronnas, 1984; Hunya et al., 1990; Murgescu, 2010).

The second main driving force of economic growth was the redirection of agricultural working force towards industrial production and the large scale inclusion of female workers. As Table 1 shows, the share of active work force employed in agriculture fell from $73.8 \%$ in 1950 to $27.9 \%$ in 1989. The table also highlights that this rapid transformation considerably slowed down during the 1980s.

Table 1: The total number of employees and distribution by sector in Romania (1950-1989)

\begin{tabular}{ccccc}
\hline & $\begin{array}{c}\text { Total number of } \\
\text { employees (million) }\end{array}$ & Agriculture (\%) & Industry (\%) & Services (\%) \\
\hline 1950 & 8.4 & 73.8 & 14.3 & 11.9 \\
1960 & 9.5 & 65.3 & 20.0 & 14.7 \\
1970 & 9.9 & 49.5 & 30.3 & 20.2 \\
1980 & 10.4 & 30.8 & 43.3 & 26.0 \\
1989 & 10.9 & 27.9 & 45.1 & 27.0 \\
\hline
\end{tabular}

Sources: Statistical Yearbook 1990, pp.102-110; Murgescu, 2010, p.340.

${ }^{4} 80 \%$ of industrial investments were received by production oriented industries (Murgescu, 2010, p.338). 
The importance of the late 1970s is evident if we look at data concerning economic growth. Whereas between 1950 and 1979 one can witness a dynamic economic growth, in 1980 a two-decade-long economic stagnation and downturn started.

Table 2: Economic growth rate in Romania between 1950 and 2010 (\%)

\begin{tabular}{cccc} 
Period & $\begin{array}{c}\text { Economic growth } \\
\text { (annual average) }\end{array}$ & Period & $\begin{array}{c}\text { Economic growth } \\
\text { (annual average) }\end{array}$ \\
$1950-1954$ & 6.1 & $1985-1989$ & -1.1 \\
$1955-1959$ & 3.6 & $1990-1994$ & -5.2 \\
$1960-1964$ & 4.8 & $1995-1999$ & 0.1 \\
$1965-1969$ & 4.6 & $2000-2004$ & 5.6 \\
$1970-1974$ & 5.3 & $2005-2008$ & 6.6 \\
$1975-1979$ & 2.7 & $2009-2010$ & -3.9 \\
$1980-1984$ & 0.8 & & \\
\hline
\end{tabular}

Source: Updated version of Maddison GDP/capita database:

http://www.ggdc.net/maddison/maddison-project/data/mpd_2013-01.xlsx

The main cause of the emerging crisis of the Romanian economy was clearly the general energy crisis of the 1970s. The Romanian industry in development was characterized by rather low indicators of energy efficiency, unproblematic when energy prices are relatively low. Following the oil crisis in 1973 Romania partially counterbalanced the negative economic impact by increasing domestic oil extraction. Between 1975 and 1977 almost 80\% of the total oil consumption was secured from internal sources. After 1977, due to the depletion of sources, the internal oil production began to decline and the second oil crisis of 1979 had a rather detrimental impact on Romanian economy 5 (Părean, 2012). In addition Romania started repaying international loans taken before and this led to further loss of resources.

In due circumstances, the 1980s were marked by stagnation of economic growth, dropping investments, significant parts of the hardships incumbent to the crisis being transferred to the population.

\footnotetext{
${ }^{5}$ The second oil crisis was caused by the reduction of oil extraction in Iran after the Islamic Revolution. And Iran was the main external crude oil supplier of the Romanian economy.
} 
Figure 1: GDP per capita in Romania between 1950 and 2010

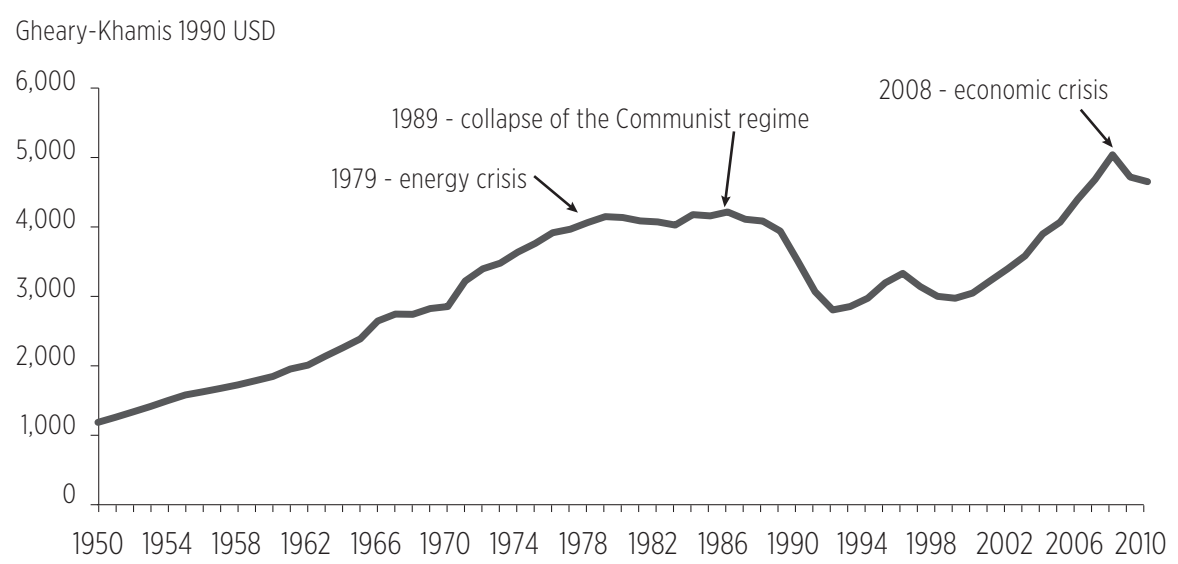

Source: Updated version of Maddison GDP/capita database:

http://www.ggdc.net/maddison/maddison-project/data/mpd_2013-01.xIsx

The economic dynamics of the country after 1989 can be divided into four distinct periods: (1) developments between 1990 and 1996, (2) between 1996 and 2000, (3) between 2001 and 2008, and (4) after 2009.

(1) The 1990s were characterized by a deep economic crisis, and not only because of the sharp decrease of GDP per capita. In the first part of the 1990s (until the electoral defeat of the post-Communist FDSN (Frontul Democratic al Salvării Nationale - Democratic Front of National Salvation), led by Ion Iliescu) cautious and slow structural reforms and the rejection of neo-liberal principles characterized the Romanian economic policies. This led to a structure labeled as "managerial capitalism" or "post-socialist managerialism" (Eyal, Szelényi and Townsley, 1997; King and Szelényi, 2005). This type of capitalism meant slow privatization (and preference for internal actors), maintaining diffuse structures of propriety, and extensive role of the state in economy. Under these circumstances, the confidence of foreign investors, and consequently the levels of FDI as related to GDP were rather low compared to CentralEast European states applying neo-liberal principles (Hungary, Poland, Czech Republic). Despite the gradual nature of the reforms the industrial production of the country practically collapsed and a slow recovery began only in 1993. Stan and Erne (2013, p.27) also highlight that the orientation of the Romanian economy changed considerably in this period. Following the dissolution of COMECON (Council for Mutual Economic Assistance) and the loss of Middle 
East and African market, the main trade partner of the country has become the European Union.

(2) In 1996 the center-right CDR (Conventia Democratică Română - Romanian Democratic Convention) won the parliamentary and presidential elections, marking the beginning of a neo-liberal turn in economic policies. Many state owned enterprises were closed and a rapid process of privatization with foreign actors began. However, this led to a new recession and a drop of the country's industrial production. The FDI remained at rather low levels during the period between 1996 and 2000 .

The major consequence of this enduring crisis was that the number of people employed in the industrial sector fell from 4.169 million in 1989 to 2.004 million in 2000 (Murgescu, 2010, p.469). These processes are reflected in the changing structure of the Romanian economy too. If, in 1990, the value added to GDP by the industrial sector was $50 \%$ and $43.5 \%$ of the labor force was employed in industry, in 2000, the value added by the industry to the Romanian GDP was only $36 \%$ and only $26.2 \%$ of the total labor force was employed in this sector. For the same indicators, in 2010 , the values are $40 \%$ and $28.7 \%$, respectively.

Table 3: The \% of the value added to GDP by each economic sector and the \% of employees in each sector in Romania (1990-2010)

\begin{tabular}{clccccc}
\hline \multirow{3}{*}{ Agriculture } & 1990 & 1995 & 2000 & 2005 & 2010 \\
& \% value added to GDP & 24 & 21 & 13 & 10 & 7 \\
& \% employed in agriculture & 29 & 40 & 42 & 32 & 30 \\
\multirow{5}{*}{ Industry } & \% value added to GDP & 50 & 43 & 36 & 35 & 40 \\
& \% employed in industry & 43 & 31 & 26 & 30 & 28 \\
\multirow{3}{*}{ Services } & \% value added to GDP & 26 & 36 & 51 & 55 & 53 \\
& \% employed in services & 27 & 28 & 31 & 37 & 41
\end{tabular}

Sources: National Institute of Statistics, World Bank.

(3) The next period, the one between 2000 and 2008, was characterized by an intensive growth of the Romanian economy. Following 2000, both leftand right-wing governments were committed to the creation of a neo-liberal environment and to an export-oriented model of development. The context of the reforms was represented by the set of EU requirements. First, the governments introduced a strict fiscal policy to conform to the EU criteria. Second, the process of privatization was accelerated and became more open to foreign actors. 
The participation of foreign capital substantially grew in the Romanian bank system, the energetic system and in telecommunications (Murgescu, 2010, p.473). The amount of FDI also increased considerably. An industrial restructuration also began during this period and the structure of the Romanian export changed considerably (Haar, 2010). Next to labor-intensive and low value added sectors, growth of car, electrical, and metallurgical industries noticeably contributed to Romania's economic growth. With such improvements in industrial production Romania's economic structure started to come close to that of other economies of East Central Europe like Poland or Hungary, considered in the world-system paradigm as semi-peripheral countries (Berend and Ránki, 1982; Melegh, 2012). This could be considered as a sign of inclusion of the Romanian economy in the Eastern European semi-periphery. Still, many features characteristic for peripheral economies persisted. This is first of all the presence of a large sector of subsistence agriculture, but the share of labor-intensive and low value added sectors, such as clothing or leather industry has remained rather high too (Haar, 2010; Stan and Erne, 2013).

(4) The rapid economic growth was interrupted by the global financial crisis in 2008 and 2009, when the economy decreased by 6.4 percentage points.

It is also important to look at relative indicators of economic position. Böröcz (2009) and Melegh (2012) argued that the relevant indicators are GDP per capita relative to world average, or the sending country's relative GDP per capita compared to the relative GDP per capita of receiving countries. Figure 2 shows Romania's economic position based on these relative indicators.

Based on the indicators we used for the analyzed period, the decline of Romania's relative global economic position is very clear. The Romanian GDP per capita was $96 \%$ of the world average in 1976, and $79 \%$ in 1989. This value fell to $52 \%$ in 2000 and reached only $68 \%$ in 2008 . So, the global position of the Romanian economy is much more unfavorable now than it was in the 1970s or 1980s. This is even more evident if we compare the Romanian GDP per capita to the average of Western European countries, the main receivers of Romanian emigrants. Second, these results show that the Romanian experience of economic development could be interpreted more properly in the framework of the world-system theory. According to Chirot (1976) the country was integrated into the global system of the capitalist economy during the nineteenth century as a peripheral society. Many Romanian historiographers interpret the last one and a half century of the Romanian history as a sequence of renewed attempts of catch-up via modernization (Boia, 1998; Murgescu, 2010). Relative indicators clearly show that disparities relative to European core countries have not 
diminished, however, and Romania has remained enclosed in its peripheral (or semi-peripheral) position.

Figure 2: GDP per capita in Romania compared to the world average and to the GPD per capita of seven Eastern European* and thirty Western European** countries (1926-2010)

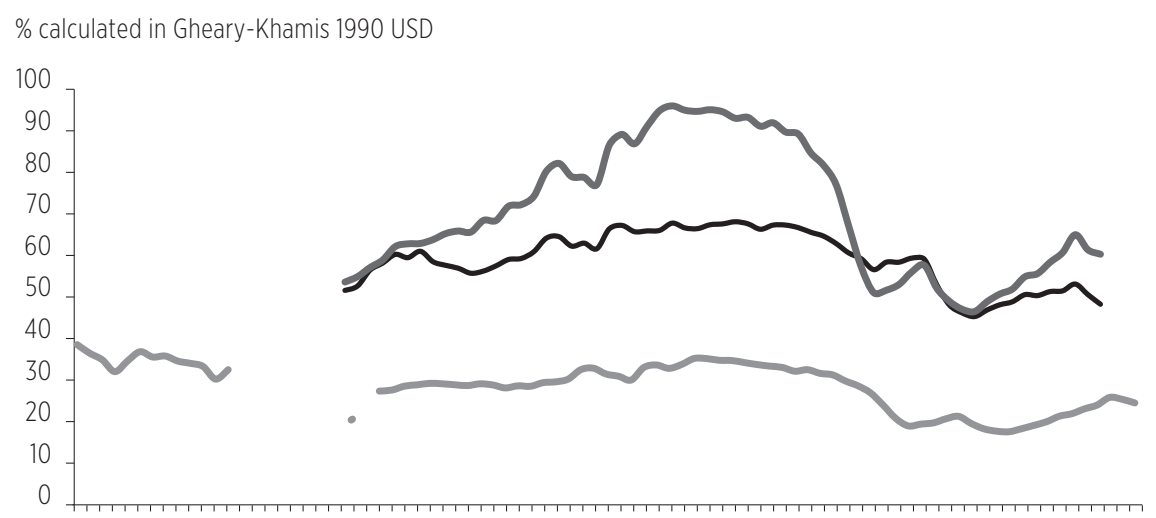

19261931193619411946195119561961196619711976198119861991199620012006

— Romania/7 Eastern Europe — Romania/World - Romania/30 Western Europe

Source: Updated version of Maddison GDP/capita database: http://www.ggdc.net/maddison/maddison-project/ data/mpd 2013-01.xlsx

Notes: * Albania, Bulgaria, (former) Czechoslovakia (later Czech Republic and Slovakia), Hungary, Yugoslavia (later the successor countries), Poland and Romania.

** Andorra, Austria, Belgium, Channel Island, Cyprus, Denmark, Faroe Islands, Finland, France, Germany, Gibraltar, Greece, Greenland, Iceland, Isle of Man, Ireland, Italy, Luxemburg, Liechtenstein, Malta, Monaco, Netherlands, Norway, Portugal, San Marino, Spain, Sweden, Switzerland and United Kingdom.

\section{Increasing inequalities}

Another important impact of the social and economic development of the last decades has been the sharp increase of social inequalities. First, we will present some of the conventional macro-indicators of social inequalities and welfareprotection. Second, we will identify several "truly disadvantaged" strata of the Romanian society and will shortly outline historical processes conductive to their situation. These strata play an important role in the history of the Romanian migration too.

Macro-level indicators, such as the Gini index, clearly show that Romania is among the most unequal societies of the EU. Prior to 1989, the Eastern European countries were characterized by rather low levels of income inequalities. After 
the collapse of state socialist regimes, income inequalities have considerably increased in all Eastern European societies. One can distinguish, however, countries with relatively low and relatively high levels of income inequalities. Hungary, Slovakia, the Czech Republic and above all Slovenia are among the countries where income inequalities are relatively low. At the opposing end of the scale, some former Soviet Republics are characterized by extreme income differences. Romania is somewhere between these two opposite ends, around the middle of the continuum. Inside the European Union, however, Romania is certainly one of the most unequal societies. It is also important that the rapid economic growth registered between 2000 and 2008 led to a sharp increase of inequalities in income.

Figure 3: The value of the Gini index in Romania, United Kingdom, Sweden and Hungary (1995-2011)

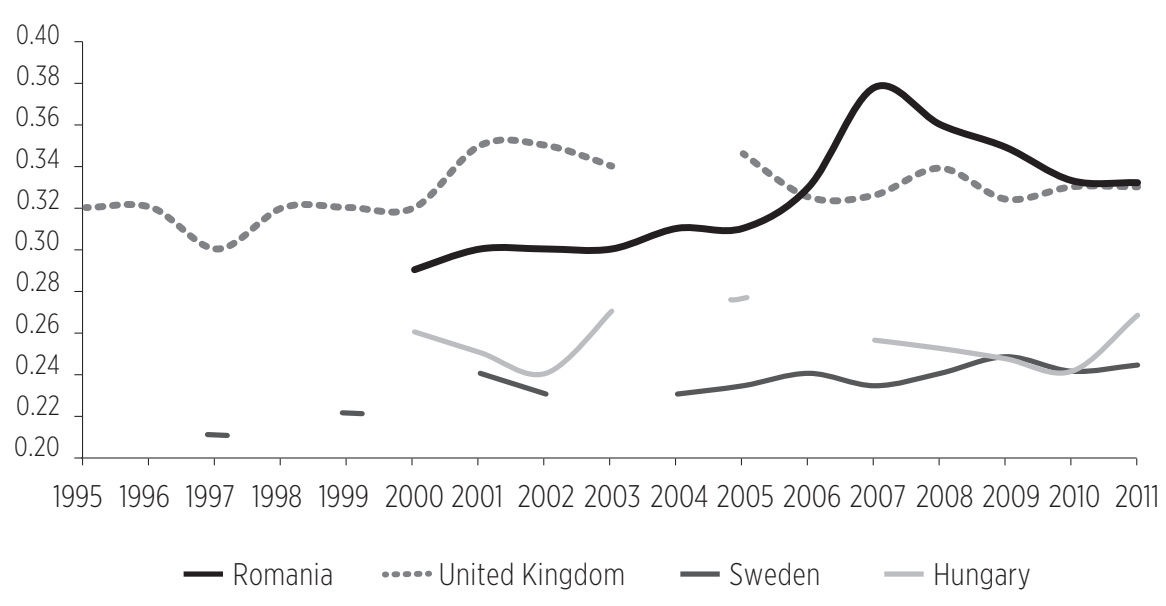

Source: Eurostat.

Without entering into details, we have to highlight that Romania is one of the EU countries that spends relatively little on social policies. In 2007, when Romania joined the EU, the member states spent $26 \%$ of their GDP on average on social protection. At the same time, in Romania, the expenditures on social protection reached only $14 \%$ of the GDP. After the financial crisis, the expenditure on social protection increased; however, it still remained at a very low level compared to other EU members. 
Table 4: Expenditure on social protection in \% of GDP in Romania and the EU (1990-2010)

\begin{tabular}{lccccccccccc} 
& 1990 & 1995 & 2000 & 2000 & 2000 & 2000 & 2000 & 2000 & 2000 & 2000 & 2010 \\
\hline EU (27 countries) & 24 & 21 & 13 & 13 & 13 & 13 & 13 & 13 & 13 & 13 & 7 \\
Romania & 27 & 28 & 31 & 31 & 31 & 31 & 31 & 31 & 31 & 31 & 41 \\
\hline
\end{tabular}

Source: Eurostat.

Next to rather abstract macro-level indicators the most obvious form of social inequalities should be mentioned, namely spatial inequalities.

First, the precarious situation of small towns should be mentioned. The industrialization of small towns began in the 1970s, following the administrative re-organization of the country. ${ }^{6}$ Many of them received the status of town in this period. In spite of the relatively significant amount of industrial investment, these settlements were clearly disadvantaged in terms of investment in urban infrastructure and housing. As industrial investments had been usually quite unilateral, small towns had the most chances to become dependent on a sole industry, or as Ioniță (2007) labeled their situation to become "mono-industrial ghettos". In such mono-industrial settlements the whole economic and social life tended to gravitate around the single workplace (the factory or the mine). As a consequence, the deindustrialization hit them particularly hard. Bănică, Istrate and Tudora (2013, p.288) argued that in mono-industrial small towns the consequence of the industrial collapse was a kind of "de-economization", meaning the reduction of a wide range of services and employment opportunities. Another consequence has been re-ruralization, meaning the retreat of the former industrial workers into subsistence agricultural activity and the giving up of certain "urban facilities" such as central heating.

Another group hit particularly hard by deindustrialization was commuters (navetiști in Romanian). Szelényi (1996) noted that the Eastern European state-socialist social structure, compared to other parts of the world, was characterized by severe under-urbanization. This meant that the demand for labor force of urban/industrial workplaces exceeded by far the number of those moving from rural to urban areas. In the 1970s and 1980s, the phenomenon of commuting was widespread in Romania, and a significant part of the rural population was employed in urban units of production. Table 1 above shows that

\footnotetext{
${ }^{6}$ The present administrative structure of the country based on counties, towns, communes and municipalities was established in 1968. This led also to a territorial reorganization of the investments (see Ronnås, 1984).
} 
in 1989 "only" $28 \%$ of the total labor force was employed in agriculture, though the proportion of the rural population was 45\%. After 1990, the first victims of deindustrialization were precisely the commuters. Their number decreased sharply following the change of the regime. Former commuters also tended to be engaged in subsistence farming.

A remarkable change occurred concerning the patterns of Romanian internal migration. From the 1950s until the 1990s, the prevailing direction of migration was from the rural to the urban. From 1992, the direction changed. The number of those moving from rural areas to urban settlements started to decrease, conversely, the mobility in the opposite direction (from urban to rural) increased. In 1997 the migrants from urban to rural outnumbered those moving from rural to urban centers. This change in pattern of internal migration is also considered to be determined by the process of deindustrialization. One of the first reactions of the population to the shrinking labor market was to return to the villages. They were primarily those persons (or their children) who moved to urban areas (and first of all to small mono-industrial towns) in the previous decades. The bulk of those returning also became active in agriculture and was mostly engaged in subsistence farming (Ghețău, 2007, pp.36-37; Ronnås, 1995).

During the 1990s, employment in agriculture grew not only in relative but in absolute terms as well. In 1990, 3 million people were employed in agriculture, and this number grew to 3.5 million until 2000 (Murgescu 2010, p.470). After the turn of the millennium, the number of employees in agriculture began to fall. This process was determined by two factors: the economic recovery, which led to an increasing demand of labor force primarily in construction and certain service sectors, and the intensification of emigration. Figure 4 shows that the value added to the Romanian GDP by agriculture has been declining continuously in spite of the growing share of those working in agriculture. In 1990, the value added by agriculture was $24 \%$, but only $7 \%$ in 2010 . Those who were forced by the structural changes of Romanian economy to withdraw to subsistence farming feed rural poverty and enduring marginalization. The sharp decline of the productivity of Romanian agriculture was caused primarily by the agrarian policies. The collective farms were abolished shortly after the change of the regime. In 1990, the restitution of land properties began too. This resulted in hundreds of thousands of farms well below the optimal size. The restitution of land properties was actually used by the Romanian political class as a substitute to social policies. The existence of a large group of subsistence farmers, along with the collapse of the industry, can be considered the main push factor in the emigration of Romanians. Due to the possibility of emigration and the high 
prevalence of subsistence farming, the unemployment rate did not reach very high levels in spite of the massive deindustrialization.

Figure 4: The value added to GDP by agriculture and the proportion of those employed in agriculture in Romania (1980-2011, \%)

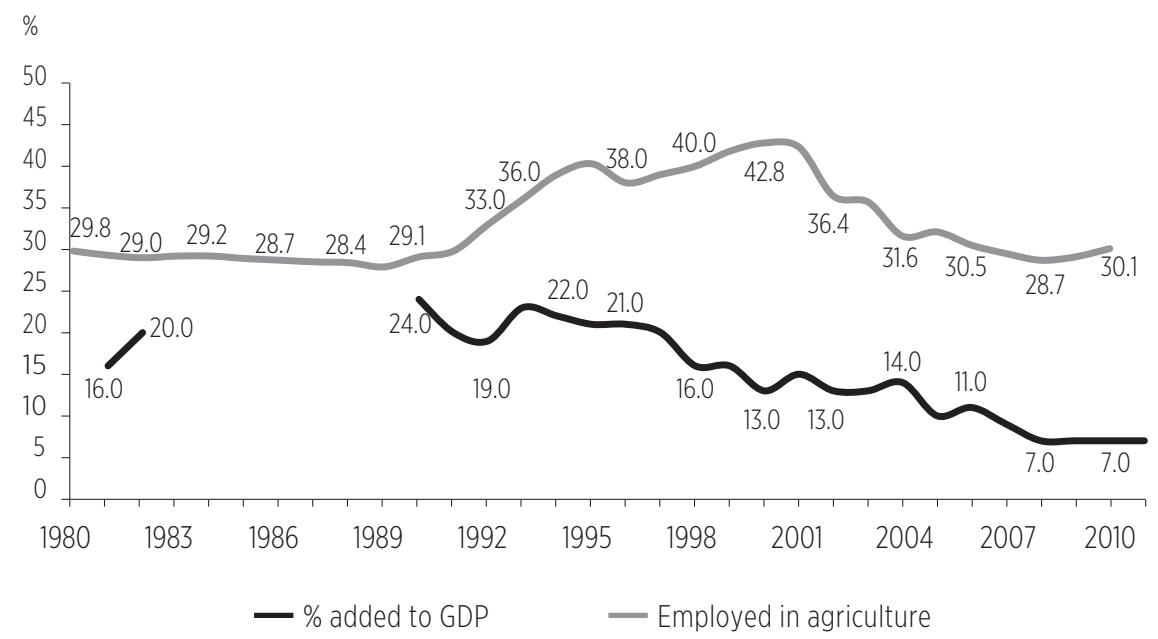

Sources: National Institute of Statistics, World Bank.

\section{MAIN INTERNATIONAL MIGRATION TRENDS AND THE MAIN CHARACTERISTICS OF MIGRANTS}

During the period between 1950 and 2011, Romania was primarily an emigration country. We will first describe the changing process of emigration and then will turn to shortly describe inflows. As for immigration, we will pay attention to migration from Moldova, a Romanian-speaking country next to Romania's border. We will show that in spite of Romanian efforts to promote cross-border ties, Romania has not been receiving the majority of Moldovan emigrants.

The term of migration regime could be useful to define periods of Romanian emigration. According to Hováth and Anghel (2009, p.19) international migration regime is the constellation of exit, entrance and incorporation policies that citizens of a given sending country are subjected to, that shapes to a great extent individual migrants' careers and biographies. It includes first of all the possibilities to leave the sending country, namely access to passport, filters 
used to select potential emigrants by sending authorities and even the cost and risks of travelling abroad. Second, it also includes the possibility of entering the receiving country: visa regime, border control etc. Legal and social aspects of immigrant incorporation are also part of the migration regime (chances to obtain the status of legal emigrant, refugee status, long-term residence, citizenship etc.).

The migration regimes have altered considerably during the period investigated. First, one can distinguish between a Cold War and a post-Cold War regime of migration. The Cold-War regime of migration in Romania was characterized by limited chances of exit (passports were retained by authorities and issued biannually strictly for the period of the journey abroad) and high risks of crossing the border illegally. As a consequence, it was very difficult to reach the most desired (Western) countries of destination. However, Romanian migrants had no difficulty in gaining admission to Western countries. Furthermore, if they were successful in entering, they easily gained legal (refugee and immigrant) status. The channels of migrant integration were also predictable. The Cold-War migratory regime changed gradually to another type in the 1980s and early 1990s. The ability of the Romanian state to control outflows declined considerably already during the late 1980s. Refugees and illegal emigrants started to cross the Romanian-Hungarian border in considerable numbers in 1986. At the beginning, they were trying to reach Austria in order to seek asylum; however, in the circumstances of the vacillating attitude of the Austrian authorities an increasing number of Romanian citizens remained illegally in Hungary. Hungary first tolerated the increasing illegal stock, thereafter adopted the necessary legislation to offer the asylum (Szőke, 1992, p.308).

The restrictions to leave Romania were abolished immediately after the collapse of the communist regime. In due circumstances the number of asylum requests submitted by Romanian citizens was high, but as a counteraction to the outflow, during the early 1990s most Western European states declared Romania a safe country and introduced further restrictions for the entry of Romanian citizens. Some of the analysts used the metaphor of "fortress Europe" to describe the change (Fassmann and Münz, 1994) or talked about the fear of "refugees of hunger" (Diminescu, 2009). The restrictions have been gradually abolished following the turn of the Millennium. In 2002, the requirement to gain visa into EU countries was lifted. Following the 2007 EU accession, Romanian citizens could stay in EU countries without restrictions and the labor market of EU countries has been also gradually opened. 


\section{The general trend and periods of migration during state socialism}

As previously mentioned, despite the closed borders, the history of the Romanian state-socialist regime is by far not one of a complete stoppage of emigration. Between 1948 and 1989, a relatively high net migration loss (783,578 persons) was officially registered (Muntele, 2003, p.36). The bulk of emigrants for this period belonged to various minorities: Jews (Bines, 1998; Ioanid, 2005), Germans (Fassmann and Münz, 1994; Münz and Ohliger, 2001) and Hungarians (Horváth, 2005). Emigration, however, was not exclusively reduced to ethnic minorities; some other channels were still accessible for other categories of citizens too. Such channels were represented by family reunification and asylum.

The state socialist period was characterized by a significant oscillation in terms of emigration opportunities. In this respect, the following five distinct periods can be identified (based on Muntele, 2003, pp.36-37):

(1) The period between 1945 and 1953 was characterized by relatively large number of emigrants, many of them belonging to the economic and intellectual elites of the interwar regime. Furthermore, the first wave of mass-migration of the Jewish community from Romania took place in this period, and about 116,000 Jewish people left the country.

(2) The period between 1953 and 1956 was characterized by limited outflows and considerable inflows/remigration of Romanian citizens. Remigration included many persons formerly deported to the USSR, who were released after Stalin's death.

(3) Between 1957 and 1965, there was a significant increase in emigration. This consisted primarily of the second wave of Jewish mass-migration.

(4) Between 1966 and 1978, the emigration rate fluctuated considerably. After Ceauşescu's rise to power, according to the new lines in population policies, the control of out-migration was readily observable. From the early 1970s, however, the out-migration of ethnic minorities (primarily Jews) was permitted again, and by the end of the period ethnic Germans started to migrate too. Moreover, at the beginning of this period, there were more liberal policies with regard to migration for study purpose, thus the international mobility of the Romanian academia and that of highly skilled labor force was also allowed.

(5) Between 1978 and 1989, the number of officially registered emigrants sharply increased. This was due, first of all, to the mass migration of ethnic Germans to Germany. According to the 1977 census data, 358,373 persons 
declared themselves as belonging to the German minority. According to an agreement between Romania and Western Germany, in the time period between 1978 and 1989 12,000 Germans could leave the country annually.

During state socialism, temporary labor migration was exclusively statemanaged, and not very significant in terms of its volume. A large majority of Romanian workers headed to the Middle East, particularly to the Persian Gulf area, where their labor activities were tightly regulated and family reunification was forbidden (Salt, 1989). The inflow of foreign immigrants was rather limited during state socialism. However, foreign students (especially from the Middle East and African countries) were well represented at Romanian universities from the 1970s onwards. At its peak, the annual stock of foreign students rose to 16,900, representing 7-8\% of all students registered at Romanian universities in 1981 (OECD, 1994).

Figure 5: Number of officially registered emigrants in Romania between 1957 and 1989

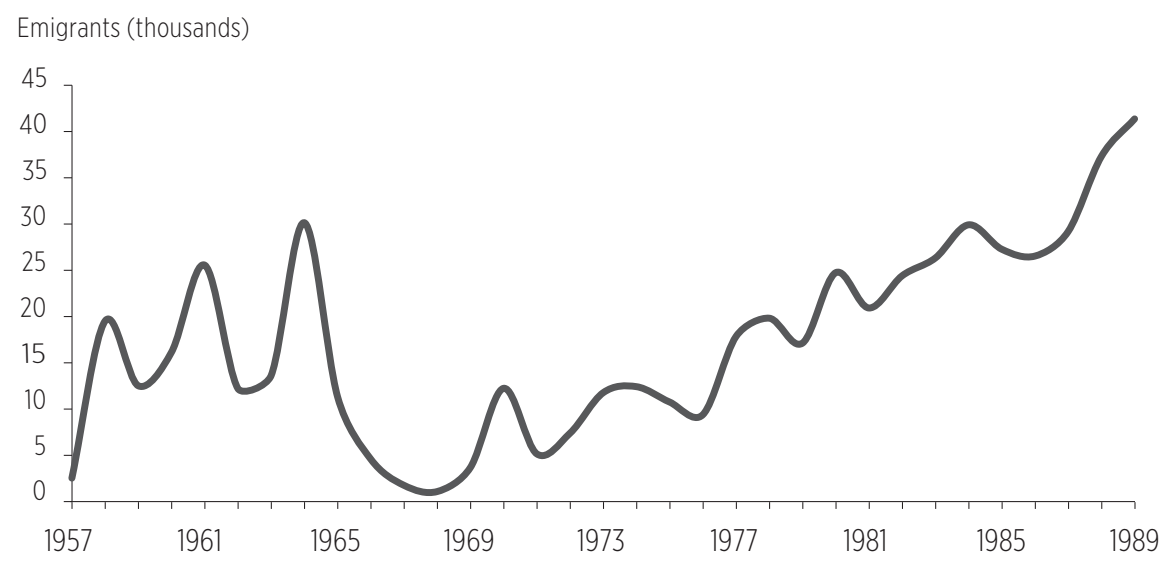

Sources: OECD, 1994. „Trends in International Migration. Continuous Reporting System on Migration Annual Report 1993." Organization for Economic Cooperation and Development, Paris. (based on reports of the Romanian Ministry of Internal Affairs).

Two remarks should be made concerning outflows during the state-socialist period. First, statistics concerning emigration were relatively reliable. Until the late 1980s, the Romanian state had the ability to control outflows. Nevertheless, the number of real emigrants was higher than the officially registered outflows. Tompea and Năstuța (2009, p.221) compared the official Romanian figures concerning the number of emigrants to Germany and the German figures concerning the immigrants from Romania and found that the figure 
registered by German authorities was higher by $15 \%$ compared to the figure registered by Romanian authorities. The number of irregular emigrants grew drastically in the late 1980s. Hungarian authorities registered 47,771 immigrants from Romania between 1986 and 1989 and - as already mentioned - for a great number of illegal migrants Hungary represented only a transit country (Szőke, 1992).

Second, ethnic preferences of the Romanian state were clear. The Romanian state allowed Jews and Germans to migrate, while the transnational mobility of other categories of Romanian citizens was drastically restricted. We can assume that this process was motivated by nationalism, demographic engineering and a from of ethnic un-mixing related to the ethnic selectivity and proactivity of German and Israeli immigration policies (Brubaker, 1998).

\section{General trends and periods of emigration after 1989}

The change of the migratory regime following the fall of the regime had an additional consequence. The Romanian statistical system practically collapsed. As a consequence, one cannot rely on official Romanian statistics concerning emigration when analyzing outflows (Kiss, 2015). Mirror statistics could be considered more reliable. As for migration flows, we used the OECD International Migration Database (2016), which covers the most important receiving countries of Romanian immigrants.

Three major changes of the migratory regime could be identified. The first was in 1989, when the state socialist regime collapsed, the second in 2002, when Romanians were exempted from visa requirements in EU countries, and the third in 2007, when Romania joined the EU. Data show that all these major changes of migratory regime led to considerable increase in inflows of Romanian immigrants in OECD countries. The most important increase was in 2007, when more than 500.000 Romanians entered officially OECD countries. The highest numbers were registered in Italy and Spain. The increase in outflows following the liberalization of the migratory regime shows that a cumulated migratory potential existed previously. Nevertheless, the EU accession in 2007 was also an opportunity for many illegal migrants to legalize their status. 
Figure 6: Annual inflows of Romanian immigrants in OECD countries (1988-2013)

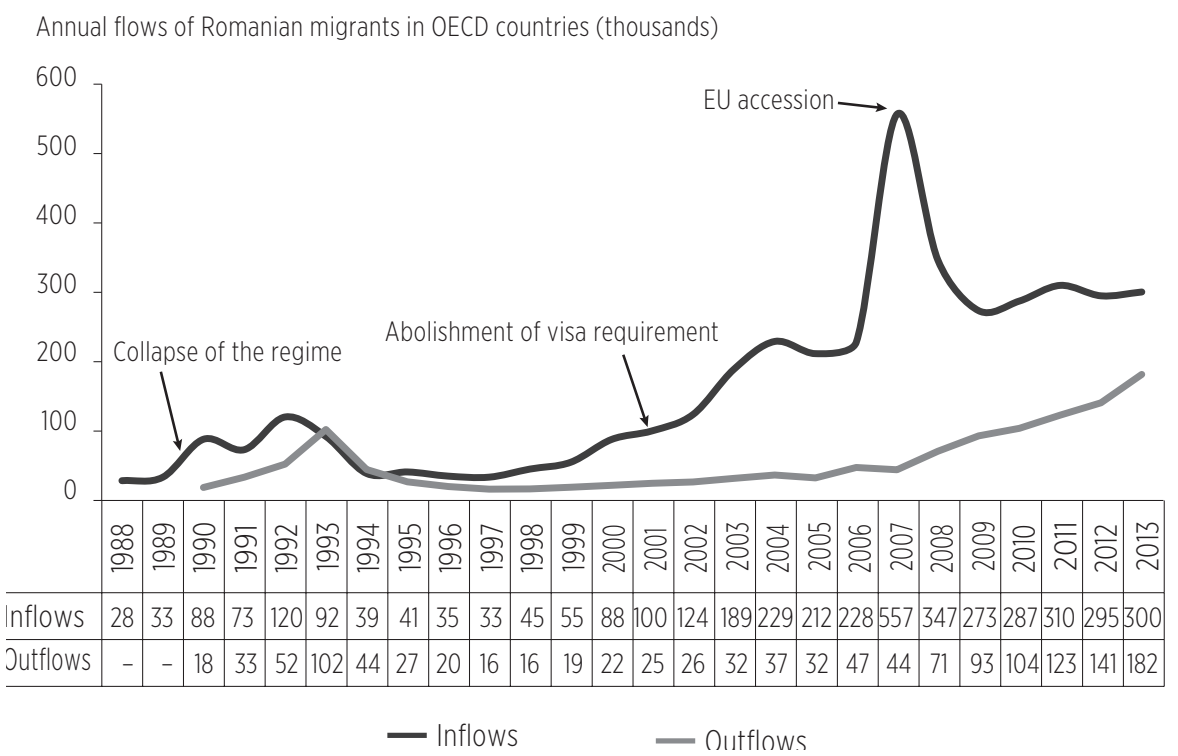

Source: OECD International Migration Database.

Figure 7: Annual inflows of Romanian immigrants in Italy (1998-2013)

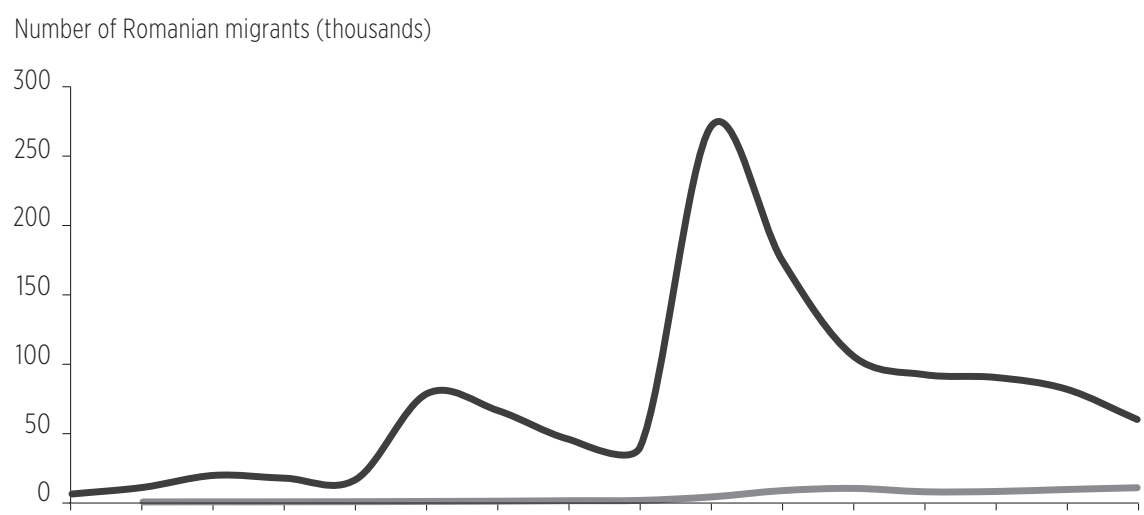

1998199920002001200220032004200520062007200820092010201120122013 — Inflows - Outflows

Source: OECD International Migration Database. 
Outflows have also varied considerably. The first massive wave of repatriation of Romanian migrants was in 1992-1993. Immediately after 1990, a massive flux of Romanian asylum seekers entered different Western European states (the bulk of them Germany). In order to curb the flow of Romanian asylum seekers, many western European states, most importantly Germany (starting from 1992), amended the law on asylum and reconsidered in the status of Romania, qualifying it as a "safe country of origin". Furthermore, a bilateral agreement between Germany and Romania stipulated the repatriation of Romanian citizens failing to obtain the refugee status (Reermann, 1997, p.127). As a result of these policy measures, the number of Romanian asylum seekers abruptly decreased, this strategy of emigration was adopted by a decreasing number of Romanian citizens.

Figure 8: Annual inflows of Romanian immigrants in Germany (1990-2013)

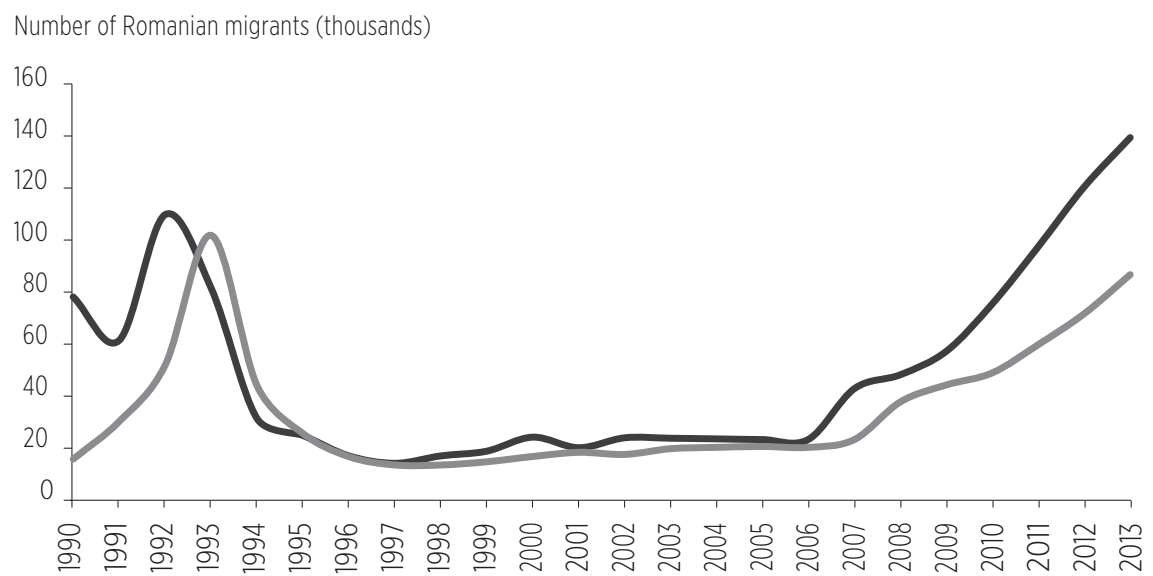

$$
\text { - Inflows - Outflows }
$$

Source: OECD International Migration Database.

A second increase in outflows occurred following the country's EU accession. The causes of this increase could be multiple. First, it is largely acknowledged that more permissive migratory regimes lead to increased frequency of circulation. In contrary cases (e.g. under restrictive regimes), migrants tend to prolong their staying at the "safe side" of the border. Second, Spanish authorities reintroduced restrictions concerning the entrance of Romanian (and Bulgarian) labor force in 2013 (Moreh, 2014). As a consequence, the number of 
Romanians entering Spain was lower than those leaving the country. And third, Germany has become the most important receiving country. In Germany the circular character of the migratory flows seems to be more accentuated than in the case of Spain and Italy.

Figure 9: Annual inflows of Romanian immigrants in Spain (1997-2013)

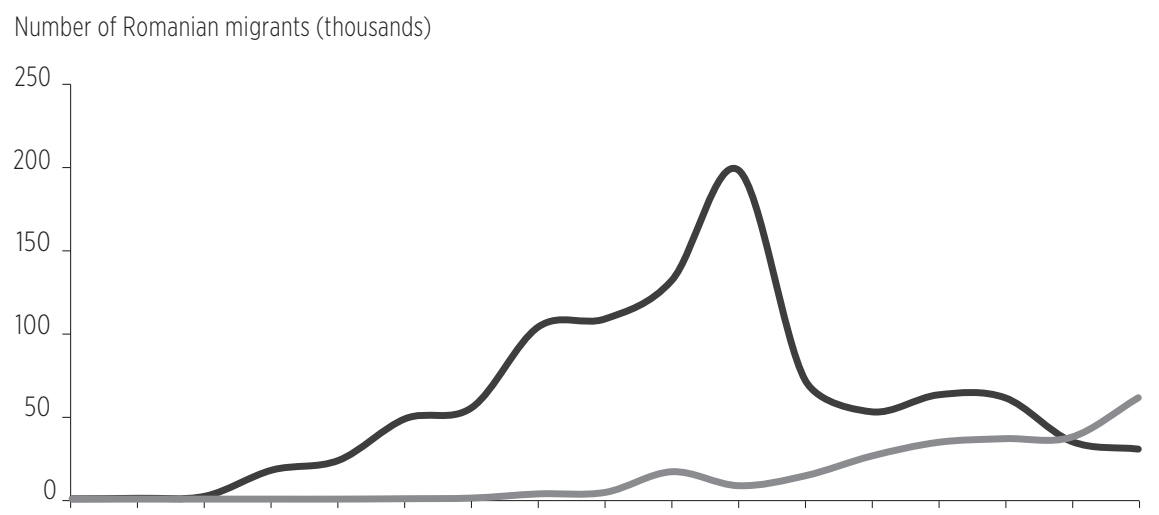

19971998199920002001200220032004200520062007200820092010201120122013

$$
\text { - Inflows - Outflows }
$$

Source: OECD International Migration Database.

As for emigrant stock, the World Bank's bilateral migration matrix can be used. ${ }^{7}$ This data source also indicates the changing significance of different destination countries. In 1990 a huge amount of Romanian immigrants resided in Germany. Their number was reduced considerably (most probably due both to naturalization and return) until 2010. During the period between 2010 and 2013, the number of Romanian immigrants in Germany rose again. It is also obvious that the relative significance of countries such as Israel and Hungary has somewhat declined. The drop of the Romanian immigrants in Spain following 2010 is confirmed by this data source too.

\footnotetext{
${ }^{7}$ We should note that different data sources concerning Romanian emigrant stock (Eurostat, OECD International Migration Database) are inconsistent (see Horváth and Kiss, 2013).
} 
Table 5: The stock of Romanian immigrants in main receiving countries (1990-2013)

\begin{tabular}{|c|c|c|c|c|}
\hline & 1990 & 2000 & 2010 & 2013 \\
\hline Italy & 15725 & 123957 & 813037 & 1008169 \\
\hline Spain & 765 & 47854 & 810471 & 800400 \\
\hline Germany & 1144848 & 324085 & 134911 & 438000 \\
\hline Hungary & 139690 & 133077 & 189055 & 232793 \\
\hline US & 101256 & 140085 & 171253 & 188638 \\
\hline Israel & 151154 & 139278 & 182099 & 105488 \\
\hline United Kingdom & 4031 & 21684 & 53081 & 103421 \\
\hline Canada & 29887 & 59644 & 96209 & 95499 \\
\hline Austria & 28723 & 24647 & 56932 & 73900 \\
\hline France & 15725 & 123957 & 54305 & 57689 \\
\hline Belgium & 168 & 2487 & 21634 & 52700 \\
\hline Greece & 4762 & 21132 & 45289 & 38597 \\
\hline Turkey & 9324 & 20853 & 23232 & 30706 \\
\hline Portugal & 76 & 3008 & 3954 & 23513 \\
\hline Sweden & 7991 & 11646 & 16184 & 23299 \\
\hline Australia & 10932 & 12700 & 17449 & 18130 \\
\hline Ireland & 423 & 5264 & 12682 & 17800 \\
\hline Switzerland & 29152 & 3146 & 7914 & 14624 \\
\hline Denmark & 952 & 2017 & 4186 & 13615 \\
\hline Netherland & 2361 & 4822 & 8716 & 13606 \\
\hline Czech Republic & 852 & 12066 & 12083 & 12800 \\
\hline Norway & 290 & 1105 & 2045 & 10278 \\
\hline Slovak Republic & 147 & 3178 & 2751 & 5300 \\
\hline Poland & 4986 & 3623 & 3632 & 2659 \\
\hline Total (countries above) & 1704220 & 1245315 & 2743103 & 3381624 \\
\hline Total (worldwide) & 1761648 & 1307973 & 2769053 & 3430476 \\
\hline
\end{tabular}

Source: World Bank Bilateral Migration Database.

One can identify several distinct phases of the Romanian emigration following 1989 (Baldwin-Edwards, 2005; Diminescu, 2009; Horváth and Anghel, 2009; Lăzăroiu, 2004; Sandu, 2006; 2010; Moreh, 2014). 
Table 6: Synthetic table of the main characteristics of Romanian emigration since 1990

\begin{tabular}{|c|c|c|c|c|}
\hline Period & $\begin{array}{l}\text { Time horizon } \\
\text { for migration }\end{array}$ & $\begin{array}{l}\text { Major countries } \\
\text { of destination }\end{array}$ & Main characteristic & $\begin{array}{l}\text { Overrepresented } \\
\text { groups }\end{array}$ \\
\hline 1990-1993 & $\begin{array}{l}\text { Definitive } \\
\text { settlement }\end{array}$ & $\begin{array}{l}\text { Germany, } \\
\text { Hungary, } \\
\text { France }\end{array}$ & $\begin{array}{l}\text { Ethnic migration; } \\
\text { Asylum seekers; } \\
\text { Legal emigrants }\end{array}$ & $\begin{array}{l}\text { Ethnic and religious } \\
\text { minorities, highly } \\
\text { skilled urban } \\
\text { professionals }\end{array}$ \\
\hline 1994-1996 & Short-term & $\begin{array}{l}\text { Israel, } \\
\text { Hungary, } \\
\text { Turkey }\end{array}$ & $\begin{array}{l}\text { Short-term labor } \\
\text { migration, frequently } \\
\text { irregular and circular }\end{array}$ & $\begin{array}{l}\text { Hungarians, urban } \\
\text { population, men }\end{array}$ \\
\hline 1997-2001 & $\begin{array}{l}\text { Short-term } \\
\text { and some } \\
\text { prospects for } \\
\text { long-term } \\
\text { residence }\end{array}$ & $\begin{array}{l}\text { Italy, } \\
\text { Spain, } \\
\text { Hungary }\end{array}$ & $\begin{array}{l}\text { Labor migration, } \\
\text { mostly irregular; } \\
\text { Prolonged } \\
\text { residence in the } \\
\text { destination countries; } \\
\text { Regularization } \\
\text { programs in Spain } \\
\text { and Italy }\end{array}$ & $\begin{array}{l}\text { Men, inhabitants } \\
\text { of small towns and } \\
\text { more developed rural } \\
\text { settlements, former } \\
\text { industrial workers }\end{array}$ \\
\hline 2002-2006 & $\begin{array}{l}\text { Prospects for } \\
\text { long-term legal } \\
\text { residence. }\end{array}$ & $\begin{array}{l}\text { Italy, } \\
\text { Spain }\end{array}$ & $\begin{array}{l}\text { Continuing processes } \\
\text { of regularization } \\
\text { involving a large } \\
\text { number of Romanians }\end{array}$ & $\begin{array}{l}\text { People coming from } \\
\text { rural areas, small } \\
\text { towns, younger age } \\
\text { groups }\end{array}$ \\
\hline $2007-2010$ & $\begin{array}{l}\text { Long-term } \\
\text { residence }\end{array}$ & $\begin{array}{l}\text { Spain, } \\
\text { Italy }\end{array}$ & $\begin{array}{l}\text { Large Romanian } \\
\text { communities in } \\
\text { Spain and Italy; legal } \\
\text { residence and formal } \\
\text { employment; labor } \\
\text { migration continues, } \\
\text { though at lower } \\
\text { levels; limited return } \\
\text { migration }\end{array}$ & $\begin{array}{l}\text { People coming from } \\
\text { rural areas, small } \\
\text { towns }\end{array}$ \\
\hline 2010- & $\begin{array}{l}\text { Short-term and } \\
\text { long-term }\end{array}$ & $\begin{array}{l}\text { Germany, } \\
\text { Italy, growing } \\
\text { significance } \\
\text { of UK }\end{array}$ & $\begin{array}{l}\text { Short-term and } \\
\text { circular migration to } \\
\text { Germany }\end{array}$ & $\begin{array}{l}\text { People of Roma } \\
\text { origin }\end{array}$ \\
\hline
\end{tabular}

Note: Modified version of the typology developed by Horváth and Anghel (2009, p.390).

(1) The first phase lasted roughly from 1990 to 1993, and it was characterized by the migration of ethnic minorities and asylum seekers. As a consequence of the liberalization of the regime of international travels, hundreds of thousands of Romanian citizens traveled abroad, many of them looking for opportunities westwards from Romania. Only a few categories were successful in finding regular emigration options: those having relatives abroad and persons belonging to the German and Hungarian minority communities. Germany actively supported, 
Hungary welcomed and offered some assistance for their ethnic kins willing to settle down (Brubaker, 1998; Horváth, 2005). Apart from these categories, many used the asylum system as a way to achieve a legalized stay at least during the application process. In the first half of the 1990s, about 350,000 Romanian citizens applied for asylum in various Western European countries. The most important country of destination was Germany (with about 75\% of asylum applications), other important destinations being Austria, France and Belgium. During this period, Romanians were (right after the citizens of the former Yugoslavia) the second largest group applying for asylum in Europe (UNCHR, 2001, pp.78-82). Among the Romanian asylum seekers the Romanian Roma were represented in high numbers (Bade 2003, p.311; Diminescu, 2009). However, this status was granted only in a few cases and many of the asylum seekers were repatriated to Romania.

(2) Between 1993 and 1996, EU countries introduced a restrictive visa regime for Romanian citizens; consequently, in the mid-1990s, westward migration remained at relatively low levels. Hungary, Turkey and Israel became the most important target countries of shorter or longer term labor migration. Israeli firms set up even labor recruitment companies in Romania. Romania's ethnic Hungarians were able to enter the Hungarian (informal) labor market (Fox, 2003; Horváth, 2005; Sik, 2006). In spite of the difficulties to penetrate the borders of the EU states, migration (primarily to Germany and France) continued, mostly in a circular way: relatively short episodes of working abroad (frequently involving irregular employment) were followed by shorter or longer episodes of staying at home (Diminescu 2003; Sandu, 2000a).

(3) Between 1997 and 2001, the importance of emigration towards non EUcountries decreased while emigration to EU countries considerably increased. The importance of Germany and France as countries of destination declined, and new target countries for Romanian labor migration started to emerge. These targets were Italy and Spain. The outflows towards Canada and the United States increased too. Official emigration, family reunification, application to different schemes for obtaining visa (Visa Lottery ${ }^{8}$, student work-and-travel programs etc.) made emigration possible mostly for highly qualified professionals. In terms of the volume of the outflows, the overseas destinations were far less important than the EU countries. Specific for this period is a change of the patterns of Romanian labor migration. In the mid-1990s, labor migration was

${ }^{8}$ In the United States, about 50,000 visas are made available yearly through the Diversity Visa Lottery Program. "According to Section 203(c) of the Immigration and Nationality Act (INA) mandated by the U.S. Congress, such Visas are made available to persons from countries that have historically low rates of immigration to the United States. A random and computer-generated drawing determines who can enter through the program." (www.visalotery.com) 
mostly irregular, short-term and circular, and destination countries were not necessarily regarded as countries of possible settlement (Sandu, 2000b). In this period an increasing number of persons developed strategies for a prolonged (though still mostly irregular) staying and considerably large immigrant stocks of Romanian origin started to emerge (especially in Italy). In parallel with this process, as Romanian citizens still needed visa to enter the EU countries, human smuggling and trafficking became rather widespread, raising serious domestic and international concern (Kane, 2005; Lăzăroiu, 2000). From 1999, attempts to regularize the flows have been undertaken and officially endorsed recruitment policies were commenced (firstly by Spain and Germany).

(4) One of the most important moments in the history of Romanian migration was 2002, when Romanian citizens were exempted from visa requirements in the majority of the EU countries. The costs and risks of emigration were reduced and, as a consequence, significantly more people engaged in migration. In parallel, various destination countries initiated programs for regularizing irregular immigration (Italy in 2002, Spain in 2005), and prospects of long-term legal residence became achievable for a considerable number of Romanian migrants.

(5) In 2007, Romania became an EU member. As a result of the new legal status of Romanian citizens within the EU there was both an increase in the volume and the legal opportunities of Romanian emigration. The highest inflows were registered in Italy and Spain.

(6) We can also confirm that a geographic relocation of the main destination countries of Romanian migrants from the Mediterranean Area to (North)Western Europe occurred between 2010 and 2013. In Spain the Romanian emigrant stock decreased, while the number of those entering the country has considerably dropped. In contrary, in countries such as Germany, the United Kingdom or Belgium the numbers increased dynamically.

It is important to note that emigration and circular migration gradually increased in Romania. Before the change of the regime, the majority of emigrants were members of ethnic minorities. Elites of the interwar area and highly skilled urban professionals were also highly overrepresented among Romanian emigrants (Muntele, 2003). In the 1990s emigrants were originating mostly from urban areas and from the western (more developed) regions of Romania. After 2002, the eastern (less developed) part of the country became the major region of origin for Romanian emigration, and the population originating from rural areas became increasingly connected with various streams of emigration (Sandu, 2006, p.19, p.24). Analysts highlighted that deindustrialization and "ruralization" 
directly affected emigration from Romanian villages and small towns (Sandu, 2006; Horváth, 2009). Villagers (former industrial workers and commuters) started to emigrate after 2000. Another interesting question is Roma migration. As previously mentioned, Roma were present in high numbers among the asylum seekers of the early 1990s (Bade, 2003; Diminescu, 2009). They were most probably underrepresented, however, among circular migrants of the 2000s. Sandu (2000a) underscored the role of pioneer-migrants in establishing stable migratory corridors ${ }^{9}$ and emphasized that, in an early stage, circular migration could be perceived as a form of social innovation. In a later stage, information concerning possibilities and experiments were diffused through existing networks, and communal models of migratory practices took shape. Social networks in Romanian villages and small towns, however, are usually ethnically divided. Because of this segregation, Roma and non-Roma living in the same settlement use regularly different migratory networks and corridors. Furthermore, according to a field research conducted in twelve Transylvanian villages and small towns in 2014, the migratory networks used by the Roma were established later than that ones used by the non-Roma. In these settlements, Roma migration has intensified especially following 2010 (Kiss, 2015). Nevertheless, the Roma have been overrepresented among this later stream of migrants.

We should also highlight that Romanian social scientists (Ghețău, 2007; Sandu, 2006; 2010) and the political elite presupposed until recently that the overwhelming majority of emigrants would return sooner or later to Romania. This assumption, however, has proved to be unrealistic. The economic crisis hit the Mediterranean countries (Spain and Italy) particularly hard, and these were the most important destination countries of Romanian emigrants. Contrary to expectations, however, the crisis did not generate significant waves of return migration. Investigations conducted among Romanian residents in Italy (Metro Media Transilvania, 2007; Mara, 2012) and Spain (Metro Media Transilvania, 2008; Moreh, 2014) showed that immigrants of Romanian origin were rather differentiated in terms of preferences concerning return. The majority of Romanian migrants did not have well defined migration plans. The majority of those who claimed to have such plans, however, expressed a preference for permanent migration, whereas short-term migration proved to be the less popular option. The recent relocation of the destination countries shows that the intensive out-migration of Romanians will most probably continue even under circumstances of population drop and ageing.

${ }^{9}$ See also Bakewell, de Haas and Kubal (2011). 


\section{Trends of immigration}

The number of registered immigrants is extremely low in Romania compared to other European countries. In 2006, one year before Romania's accession to the $\mathrm{EU}$, the total number of foreign residents in Romania was 53,606, the majority of them from Moldova, Turkey, China, Italy and Germany. Less than one third of the foreign residents were from the EU area. Only 10\% of the foreign residents possessed a permanent residence permit (Autoritatea pentru Străini, 2006, p.37). Out of the 48,177 residents with temporary residence permits, $29 \%$ were staying for studies, $18 \%$ were family members of Romanian citizens, $17 \%$ were entrepreneurs, and only $12 \%$ were labor migrants.

After 2007, intra-community mobility increased. According to data published by the Ministry of Internal Affairs, the stock of EU citizens residing in Romania increased from 15,817 in 2007 to 38,971 in 2010 (Alexe and Păunescu, 2011, p.25).

Figure 10: The stock of third country foreign nationals with a valid residence permit in Romania at the end of the year, by country of origin, between 2007 and 2011

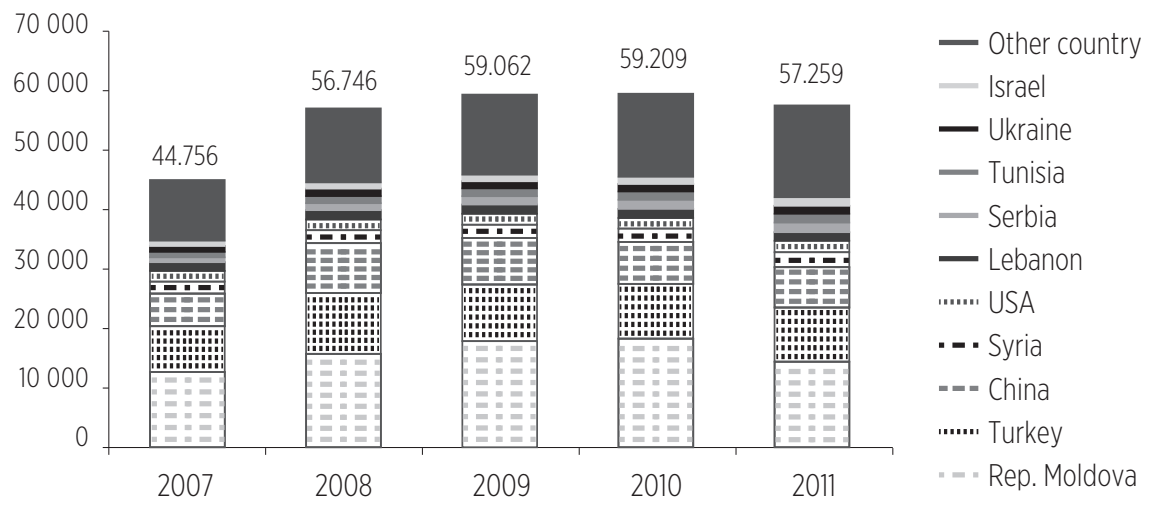

Source: The General Inspectorate for Immigration.

The stock of third country nationals (in which EU and EEA nationals are not included since 2007) also increased. In 2011, there were 57,259 legal residents, 49,282 of them having temporary residence permits. Most of these residents (50.5\%) were family members of Romanian citizens or family members of other immigrants. $25.5 \%$ of the third country nationals were students, and only $17.5 \%$ of the registered foreigners were here for labor-related (employment 
or commercial) activities (Alexe and Păunescu, 2011, p.26). The bulk of the immigrants are concentrated in the capital city or its metropolitan area. Moldova, Turkey and China are the foremost countries of origin (accounting for more than $60 \%$ of the legally residing third country nationals).

The low number of immigrants is surprising if we take into consideration Romania's "special relations" with Romanian-speaking communities next to the country's Eastern borders. Today, an approximate number of 400.000 Romanian speakers live in Ukraine, while Romanian speakers make the majority in the Republic of Moldova. They are mostly descendants of former Romanian citizens living on the territory of the interwar Greater Romania. Romania was the first Eastern European country to grant extra-territorial citizenship for most of its ethnic kin (Waterbury, 2014). The 1991 Law introduced the possibility of restituting citizenship to former Romanian citizens and it was applied to former Romanian citizens living in prewar Bessarabia and Northern Bukovina. An approximate number of 500.000 Romanian speakers from Republic of Moldova and Ukraine were naturalized between 1991 and 2014.10

In spite of the quick modification of the citizenship legislation, Romania has never been a major receiving country for Moldovan emigrants. According to the 2011 Romanian census only 37.370 persons born in Moldova and 8099 persons born in Ukraine resided in the country. A significant part of them were persons born before 1944. The World Bank's bilateral migration database shows quite similar data concerning Moldovan-born residents in Romania. The most massive Moldovan emigrant stocks were in Russia, Ukraine and (more recently) in Italy.

It is important, however, that the migration of Moldovans to Western European destinations has intensified recently. In this process Romanian citizenship policy plays an important role, as the majority of these Moldovan migrants most probably hold Romanian passport. We should also note that the Republic of Moldova is one of the world's most remittance-dependent societies (Böröcz, 2015). The most important remittance-sending countries, however, are the Russian Federation and Ukraine. Recently, the importance of Western destinations (Italy, Germany, United States) has also increased. However, remittances from Romania are far less important.

Table 7: The stock of Moldovan immigrants in main receiving countries (2010 and 2013)

\footnotetext{
${ }^{10}$ See Panainte (2013)
} 


\begin{tabular}{lrr} 
& 2010 & 2013 \\
\hline Russian Federation & 284330 & 285023 \\
Ukraine & 168370 & 157826 \\
Italy & 89188 & 151313 \\
Romania & 39091 & 49785 \\
United States & 25280 & 42471 \\
Germany & 17425 & 25805 \\
Portugal & 4287 & 20377 \\
Uzbekistan & - & 18850 \\
Spain & 17551 & 16517 \\
Israel & 21265 & 11102 \\
Other countries & 103744 & 80331 \\
World & 770528 & 859400
\end{tabular}

Source: World Bank Bilateral Migration Database.

We should note that there was a widespread expectation (connected to the model of migration transition) among Romanian scholars that Romania (as an emerging core) will become a country of immigration." This was connected not only to "developmental optimism" but also to labor-market processes. The economic dynamics of the 2000s conjoined with the amplified emigration of the Romanians (after 2002 and 2007) lead to a workforce shortage in some economic sectors, especially in constructions (both in infrastructure and housing). Under these circumstances, immigrant labor seemed to be a mid-term solution for addressing the problem. The predictions made in 2008 assuming a considerable increase in labor-motivated immigration up to a stock of 200-300,000 persons (1.1-1.4\% of the population) until 2013-2015 (Cervinschi, 2011, p.46), however, proved to be unsubstantiated. The global economic crisis curbed the ascending curve of immigration to Romania.

Nevertheless, the short period of increase provided some important lessons, as it is revealed by a comprehensive study on Chinese labor migrants (Xiao, 2010). According to this analysis, neither the authorities nor the hiring entrepreneurs were prepared to manage the influx of Chinese workers. The slow procedures and the direct and indirect administrative costs hindered the access of the Chinese people willing to work in Romania. If they eventually started to work, they received considerably lower salaries than had been

\footnotetext{
"See Horváth and Anghel (2009); Încălțaru (2011).
} 
contractually promised, the accommodation conditions and other related aspects were often improper and, in general, the employers (except for the work performed) paid little or no attention to assist immigrants in their integration into society, or to meet their specific cultural needs. In some cases tensions escalated and the entrepreneurs unilaterally abrogated the contracts, leading to the repatriation of the workers.

\section{CONCLUSIONS AND FEEDBACK TO THEORETICAL ARGUMENTS}

Our study tried to provide an overview of migratory processes in Romania since the 1950s. In our concluding remarks we would like to highlight the relevance of the historical-structural explanations and especially of the world-system theory in analyzing these long-term migratory processes. Scholars using this framework emphasize the stability and durability of migratory linkages. According to their arguments, migration is deeply embedded in a more general relationship between economic core and periphery. In fact, migration is one particular form of flows or exchanges between regions/societies characterized by asymmetric power-relations. As such, it is parallel with and inseparable from flows of capital (foreign direct investment) and forms of cultural penetration (e.g. Sassen, 1988). In this sense, Romania seems to be incorporated durably into the system of East-West type exchanges. According to Chirot (1976), the country has been integrated in the global system of capitalist production as a peripheral society. An emerging discursive order was also part of this asymmetric relationship (Wolff, 1994). As Melegh (2006) highlighted, the so called East-West slope is a historically constructed and culturally well embedded civilizational discourse, stating that there is gradual decline of civilization or development inside Europe, as one moves from West or North-West, toward East or South-East. The durable desire for catch-up type modernization and for ascending the slope of the Eastern European elites could be interpreted in this economic and discursive framework.

It is an exciting question how to interpret the state-socialist experiment, regarding the period following state socialism. State socialism was first of all a model of social modernization competing with West-centered global capitalism. It could also be interpreted as an attempt to escape structures of economic dependency and to transform relations between core and periphery. This attempt took place at different levels. First, Eastern Bloc countries led by the Soviet Union tried to establish an alternative transnational economic system. In 1962 
Khrushchev proposed the establishment of a supra-national planning authority and the synchronizing of economic investments in Eastern Bloc countries. In the proposed supranational division of labor Romania would have had a role of providing raw materials and agricultural products while industrial production (and especially heavy industry) would have been concentrated in the Soviet Union and in the more developed Eastern Bloc countries like Czechoslovakia or the German Democratic Republic. Romanian party leaders vehemently rejected the plan and in a kind of "declaration of independence"12 called for (intra-Bloc) national sovereignty and economic autarchy (Kemp, 1999, pp.149-150).

Figure 11: The number of officially registered emigrants and the Romanian GDP per capita compared to the world average during state socialism

Number of officially registred emigrants (thousands)
GDP/capita compared to world average calculated in 1990 Gheary-Khamis USD

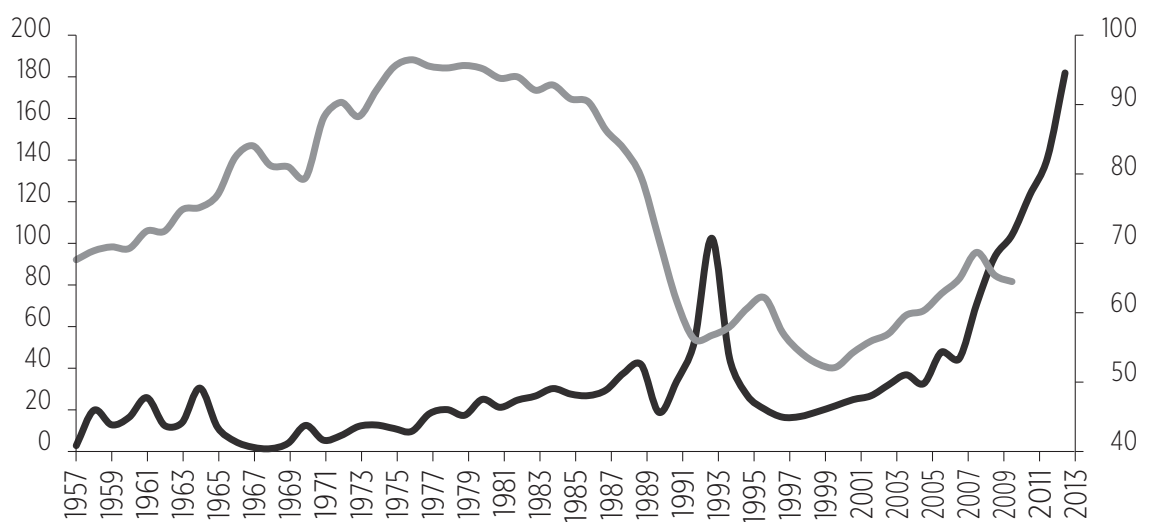

— Number of emigrants $\quad$ GDP per capita compared to the world average

Sources: Emigration: 1957-1989 official Romanian registration for emigrants; 1990-2013 officially registered immigrants in OECD countries. GDP/capita: Updated version of Maddison GDP/capita database: http://www.ggdc.net/maddison/maddison-project/data/mpd_2013-01.xlsx

National level economic and social planning could be perceived as a second attempt to escape centrum-periphery type dependency. In the Romanian case not only asymmetric East-West exchanges were rejected, but also the structure proposed by the Soviet Union. Parallel to the attempt to achieve economic autarchy the regime also tried to control population processes. In 1966 strong pro-natalist measures, among them the notorious anti-abortion legislation, were

12 Verdery (1991, p.105) used this phrasing. 
introduced (Kligman, 1996). In the case of internal and external migration state level control also played a crucial role (Sandu, 1984).

It is important to note, however, that state socialist regime was only partially and temporarily successful in transcending the asymmetric power relations inherent in the global capitalist world order. First, the economic crisis of the 1970s showed that the Romanian economy is not independent from global processes. In a period of higher oil prices the newly created Romanian industrial structure based on heavy and chemical industry proved to be unsustainable. Second, neither the state control of demographic processes was unequivocally successful. Fertility rates fell in the 1970s and 1980s, while the rural-urban migration considerably slowed down. Following the late 1960s and the early 1970s the number of emigrants also grew, while beginning with the mid-1980s the state was less and less capable to control outflows. One should also highlight that East-West migration targeting primarily Germany and Hungary did not stop during state socialism.

Even if state socialism was only partially successful in attenuating the consequences of asymmetric economic and power relations, Eastern European societies developed in a relatively protected environment before 1989. Sobotka (2002) used the notion of "socialist greenhouse" to describe an artificial environment regulating nearly all aspects of the human life-course (from professional career to reproductive behavior and family formation). Population policies and the control of migratory flows were intimately linked to this socialist greenhouse environment.

The change of the regime led to a radical shift in this institutional environment. As Böröcz (2015) highlighted, this was due to a reintegration of the Eastern European societies into the global system of capitalist production without the interference of the socialist state. In this new situation intensive and previously unexpected ideological, cultural and economic penetration also occurred. The most important form of ideological penetration was the rapid spread of neoliberalism and particularly of neoliberal system of governing (see Anghel, 2015). The most severe consequence of this ideological penetration has been that national level attempts to control population and societal processes have become not only less effective but also discredited.

At the level of ordinary people, the spread of Western patterns raised first of all consumption aspirations. Consumption patterns of the Western middle classes were widely seen as attainable and became a reference for people all across Eastern Europe (Fehérváry, 2002). These increased aspirations clashed not only with old economic realities but also with a dramatic economic decline (Thornton and Philipov, 2009). Under these circumstances, neither individual strategies of social mobility nor reproduction are enclosed within national 
society but are increasingly organized within a global hierarchical social space. Large-scale migrations from Romania are (at least partially) motivated by the ascent on the "slope", and not (only) within the social hierarchy of own society.

We also could use the concept of developmental idealism, elaborated by Thornton (2005), in a world-system theory framework. From this perspective, developmental idealism is also a form of cultural and ideological penetration. Developmental idealism, as defined by Thornton, is a set of values and beliefs connected to the evolutionist paradigm. It is based on the idea that all societies across the globe follow essentially the same developmental pathway. ${ }^{13}$ As a consequence, countries or societies could be ranked and hierarchized according their level of development (civilization, advancement etc.). People attached to developmental idealism generally claim that it is a universal model and it certainly grounds an emerging global culture (Thornton, Dorius and Swindle, 2015, p.284). However, it obviously has a strong Eurocentric and West-centric flavor, as characteristics of developed/advanced societies are equated with the characteristics of Western societies. The acceptance of developmental hierarchies, putting Western societies at the pinnacle of the developmental process is in fact a key element of developmental idealism. Another key element is the (often unfounded ${ }^{14}$ ) belief in causal mechanisms between different dimensions of development. Thornton's initial aim was to identify ideational factors conducting to the change of patterns of family formation and reproductive behavior. He emphasized that the belief that modern (e.g. Western) patterns of family formation (late marriage, low fertility, gender equality, or even more controversial elements of family formation such as acceptance of same-sex marriage, or high rates of divortiality) lead to (or at least tend to go together with) economic prosperity is an important driver of the change of reproductive behavior. Later research extended the model. Thornton, Dorius and Swindle (2015) argued that the persistent belief that free market or democracy is automatically conductive to economic wellbeing is also connected to the cultural model of developmental idealism. Thornton (2013) and Melegh (2012) also highlighted that - next to "Western" consumption aspirations - stringer belief in developmental idealism could be also a direct factor leading to higher rates of out-migration. This is not necessarily a contrary but a complementary argument to approaches stressing wage differentials.

It is also important that Romania's peripheral position inside Europe was

\footnotetext{
${ }^{13}$ Obviously, the models of mobility transition and migration cycles are connected to the same evolutionary paradigm. ${ }^{14}$ We should note that Thornton emphasized repeatedly his "agnosticism", meaning that he does not intend to defy or to defend developmental idealism. His intention is rather to understand the circumstances and consequences of its spread (see Thornton, 2005, p.135; Thornton, Dorius and Swindle, 2015, p.279).
} 
reinserted. Massive deindustrialization led to re-ruralization and to a growing sector of subsistence farming. New industrial structure characterized with the predominance of low value added braches could also be considered an indicator of a less favorable economic position. These economic processes were - next to rising consumption aspirations - direct drivers of out-migration.

As for countries of destination, historically established relations also matter. The relatively old-standing relation between Romania and Germany should be underscored. Ethnic Germans left Romania for Germany en masse during state socialism, however, migration toward Germany has not ceased following the departure of ethnic Germans. A long-standing relation exists with Hungary too. The neighboring country is continuously attractive primarily for Transylvania's ethnic Hungarians. Next to these already existing linkages, new systems of migration have also emerged. Italy and Spain were previously countries of emigration and did not have robust social or economic linkages with Romania. Due to this, the emergence of new migratory systems could be investigated through these cases. ${ }^{15}$

Historically constructed linkages should be considered in the case of immigration too. In this sense, the most exciting question is why Romania was unable to attract migrants to replace its declining population. The Romanian speaking Republic of Moldova would be an obvious location to recruit future immigrants. One should highlight that in the East European region many regional systems of ethnic migration exist. As mentioned already, Hungary is a target for ethnic Hungarians in neighboring countries, but Turkey, or Serbia is also attractive for ethnic kin living in the Balkans. Romania has a relatively active kin-state policy toward Romanian speakers of Moldova and Ukraine and extraterritorial citizenship is also offered for Romanians living in these countries. The wage- and living standard-gap between Romania and its Eastern neighbors is also considerable. If so, why is Romania unable to attract migrants from these countries? First, possibly the demand for labor force in Romania is too low. And second, the historical links to the ex-Soviet territories proved to be very resilient and, as Molodikova (2012) highlighted, there is a split between Eastern and Western systems of migration. While Central- and South-Eastern Europeans tend to migrate toward West, the primal target of CIS (Commonwealth of Independent States) country migrants is the Russian Federation. Moldova is in the intersection of these migratory systems, however, the attraction of wellestablished Russian linkage tends to be dominant.

\footnotetext{
${ }^{15}$ See in this sense Sandu (2000a, 2000b, 2006); Moreh (2014).
} 


\section{REFERENCES}

Alexe, I. and Păunescu, B., eds. (2011). Studiu asupra fenomenului imigrației în România. Integrarea străinilor în societatea românească [Study on immigration to Romania. Social integration of the foreigners in the Romanian Society]. București: Fundația Soros România.

Anghel, I. (2015). Contesting Neoliberal Governance. The Case of Romanian Roma. Social Change Review, 13(2), pp.85-111.

Autoritatea pentru Străini (2006). Migrația și azilul în România. [Immigration and asylum in Romania]. București: Autoritatea pentru Străini. Ministerul Internelor și Reformei Administrative.

Bade, K. J. (2003). Migration in European History. Oxford: Blackwell Publishing.

Bakewell, O., de Haas, H. and Kubal, A. (2011). Migratory systems, pioneers and the role of the agency. Noface Discussion Paper 23.

Baldwin-Edwards, M. (2005). Migration Policies for a Romania within the European Union: Navigating Between Scylla and Charybdis. Journal, 7. Available at: http://www.mmo.gr/pdf/publications/mmo_working_papers/MMO_WP7.pdf

Bănică, A., Istrate, M. and Tudora, D. (2013). (N)ever Becoming Urban? The Crisis of Romania's Small Towns. In: M. Naumann and A. Fischer-Tahir, eds., Peripheralization. The Making of Spatial Dependencies and Social Injustice. Wiesbaden: Springer, pp. 283-301.

Berend, I. and Ránki, Gy. (1982). The European Periphery and Industrialization. 1780-1914. Budapest: Akadémiai Kiadó

Bines, C. (1998). Din istoria imigrărilor în Israel. [Aspects of the Immigrations to Israel]. București: Editura Hasefer.

Boia, L. (1998). Istorie și mit în conștiința românească. [History and myth in the Romanian consciousness]. București: Humanitas.

Borjas, G. J. (1989). Economic Theory and International Migration. International Migration Review, 23, pp.457-485.

Böröcz, J. (2009). The European Union and Global Social Change: A Critical Geopolitical Economic Analysis. London: Routledge.

Böröcz, J. (2015). Regimes of Remittance Dependency: Global Structures and Trajectories of the Former Soviet "Bloc". Demográfia, 57(5), pp.5-37.

Brubaker, R. (1998). Migrations of Ethnic Unmixing in the New Europe. International Migration Review, 32(4), pp.1047-1065.

Cervinschi, D. (2011). Migrație și integrare. Fenomenul imigraționist și impactul programelor de integrare asupra resortisanților țărilor terțe în România. [Migration and integration. The phenomenon of immigration and the impact of the programs targeting the integration of third country nationals in Romania]. Sfera Politicii, 19(12), pp.45-55.

Chirot, D. (1976). Social Change in a Peripheral Society: the Creation of a Balkan Colony. Academic Press: New York.

De Haas, H. (2010). Migration transitions: a theoretical and empirical inquiry into the developmental drivers of international migration. Working Paper. Oxford: International Migration Institute, University of Oxford. 
De Haas, H. (2012). The Migration and Development Pendulum: A Critical View on Research and Policy. International Migration, 50(3), pp.8-25.

Diminescu, D. (2009). Exercițiul dificil al liberei circulații: o introducere în istoria migrației recente a românilor. [The exercise of free movement: an introduction into the recent migratory history of the Romanians]. In: G. R. H. Anghel and I. Horváth, eds., Sociologia migrației. Teorii și studii de caz românești [Sociology of migration. Theories and Romanian case studies]. Iași: Polirom, pp.45-64.

Diminescu, D. ed. (2003). Visibles, mais peu nombreux: les circulations migratoires roumaines [Visibles but less numerous: the Romanian circulatory migrants]. Paris: Édition de la Maison des Sciences de l'Homme.

Ene, C. and Stefănescu, A. (2011). Size and implication of underground economy in Romania - a MIMIC approach. Annales Universitatis Apulensis Series Oeconomica, 13(1), pp.77-86.

Eyal, G., Szelényi, I. and Townsley, E. (1997). Making Capitalism without Capitalists. The New Ruling Elites in Eastern Europe. London and New York: Verso.

Fassmann, H. and Münz, R. (1994). European East-West Migration, 1945-1992. International Migration Review, 28(3), pp.520-538.

Fassmann, H., Musil, E., Melegh, A. and Gruber, K. (2014). Longer-Term Demographic Dynamics in South-East Europe: Convergent, Divergent and Delayed Development. Central and Eastern European Migration Review, 3(2), pp.150-173.

Fassmann H., Musil E. and Gruber K. (2013). Dynamic Historical Analysis of Longer Term Migratory, Labour Market and Human Capital Processes in Austria. Country report developed within the project 'SEEMIG Managing Migration and Its Effects Transnational Actions Towards Evidence Based Strategies.'

Fassmann, H. and Reeger, U. (2012). Old Immigration Countries in Europe. The Concept and Empirical Examples. In: M. Okólski, ed., European Immigrations. Trends, Structures and Policy Implications. Amsterdam: Amsterdam University Press, pp.65-90.

Fehérváry, K. (2002). American Kitchens, Luxury Bathrooms, and the Search for a 'Normal' Life in Post-Socialist Hungary. Ethnos, 67(3), pp.369-400.

Fox, J. (2003). National identities on the move: Transylvanian Hungarian labour migrants in Hungary. Journal of Ethnic and Migration Studies, 29(3), pp.449-466.

Ghețău, V. (2007). Declinul demografic și viitorul populației României. O perspectivă din anul 2007 asupra populației României în secolul 21. [The demographic decline and the prospects of Romania. A 2007 perspective on the Romanian population processes in the 21th century]. București: Editura Alpha.

Haar, L. (2010). Industrial Restructuring in Romania from a Bilateral Trade Perspective: Manufacturing Exports to the EU from 1995 to 2006. Europe-Asia Studies, 62, pp.779-805.

Horváth, I. (2005). Változó környezet állandósuló trendek? [Changing environment and permanent trends?]. In: I. Horváth, ed., Erdély és Magyarország közötti migrációs folyamatok. [Migration processes between Transylvania and Hungary]. Kolozsvár: Sciencia Kiadó. pp.9-132

Horváth, I. (2007). Country profile Romania. Focus Migration country profiles, 9, pp.1-10. 
Horváth, I. (2009). Aspectele ale culturii migrației în România. [Aspects of the culture of migration in Romania]. In: R., Anghel, and I. Horváth, eds., Sociologia Migrației. Teorii și sudii de caz românești. [Sociology of migration. Theories and Romanian case studies]. Iași: Polirom, pp.14-44.

Horváth, I., and Anghel, R. (2009). Migration and Its Consequences for Romania. Südosteuropa, 57, pp.386-403.

Horváth, I., and Kiss, T. (2013): Dynamic Historical Analysis of Longer Term Migratory, Labour Market and Human Capital Processes in Romania. Country report developed within the project 'SEEMIG Managing Migration and Its Effects - Transnational Actions Towards Evidence Based Strategies'.

Hunya, G., Réti, T., Süle, A. R. and Tóth, L. (1990). Románia 1944-1990. Gazdaság-és politikatörténet. [Romania 1944-1990. Economic and Political History]. Budapest: Atlantisz Kiadó.

Încălțaru, C. (2011). Toward Migration Transition in Romania. CES Working Papers 4.

Ioanid, R. (2005). The Ransom of the Jews: The Story of Extraordinary Secret Bargain Between Romania and Israel. Chicago: Ivan R. Dee.

Ioniță, S. (2007). Pledoarie pentru orașele mici. [Pledge for the small towns]. Available at: http://www.evz.ro [Accessed 15 July 2016].

Kane, J. (2005). Child Trafficking - The People Involved. A synthesis of findings from Albania, Moldova, Romania and Ukraine. Geneva: IPEC-ILO.

Kemp, W. (1999). Nationalism and Communism in Eastern Europe and the Soviet Union. A Basic Contradiction. London: Palgrave-Macmillan.

King, L. and Szelényi, I. (2005). Theories of the New Class: Intellectuals and Power. Minneapolis: Minnesota University Press.

Kiss, T. (2013). Analysis of existing migratory data production systems and major data sources in Romania. Country report developed within the project 'SEEMIG Managing Migration and Its Effects - Transnational Actions Towards Evidence Based Strategies.

Kiss, T. (2015). Migratory Patterns in Twelve Roma Settlements. Manuscript.

Kligman, G. (1996). The Politics of Duplicity: Controlling Reproduction in Ceausescu's Romania. Bekerley - Los Angeles: University of California Press.

Kligman, G. and Verdery, K. (2012). Peasants under Siege. The Collectivization of the Romanian Agriculture, 1949-1962. Princeton: Princeton University Press.

Lăzăroiu, S. (2000). Trafic de femei - O perspectivă sociologică. [Female Trafficking - a sociological perspective]. Sociologie Românească, 2, pp.57-79.

Lăzăroiu, S. ed. (2004). More Out' than In' at the Crossroads between Europe and the Balkans (Vol. IV). Vienna: International Organization for Migration.

Mara, I. (2012) Surveying Romanian Migrants in Italy Before and After the EU Accession: Migration Plans, Labour Market Features and Social Inclusion. Vienna: The Vienna Institute for International Economic Studies.

Melegh, A. (2006). On the East-West Slope. Globalization, Nationalism, Racism and Discourses on Central and Eastern Europe. Budapest: Central European University Press.

Melegh, A. (2011). A globalizáció és migráció Magyarországon. [Globalization and migration in Hungary]. Educatio, 2, pp.166-180 
Melegh, A. (2012). Net Migration and Historical Development in Southeastern Europe since 1950. Hungarian Historical Review, 1(3-4), pp.415-453.

Metro Media Transilvania (2007). Comunitatea românească în Italia: condiții sociale, valori, assteptări. [The Romanian community in Italy: social conditions, values, expectations]. Studiu sociologic: Agenția pentru Strategii Guvernamentale.

Metro Media Transilvania (2008). Comunitatea românească în Spania: condiții sociale, valori, așteptări. [The Romanian community in Spain: social conditions, values, expectations]. Studiu sociologic: Agenția pentru Strategii Guvernamentale.

Molodikova, I. (2012). Demographic situation in CIS countries and the relations with EU. Presentation at SEEMIG Conference, 19 September, Bratislava.

Moreh, C. (2014). Alcalái románok. Migráció és társadalmi differenciálódás. [The Romanians of Alcala. Migration and social differentiation]. Budapest: L'Hartmattan.

Muntele, I. (2003). Migrations internationales dans la Roumanie moderne et contemporaine. [International migrations in modern and contemporary Romania]. In: D. Diminescu, ed., Visibles mais peu nombreux. [Seen but not many]. Paris: Editions de la Maison des sciences de l'homme, pp.33-51.

Münz, R. and Ohliger, R. (2001). Migrations of German people to Germany: a light on the German concept of identity. The International Scope Review, 3(6), pp.60-74.

Murgescu, B. (2010). Romania și Europa. Acumularea decalajelor economice (1500-2010). [Romania and Europe. The accumulation of economic disadvanteges]. Iași: Polirom.

Notestein, F. W. (1945). Population: The Long View. In: T. W. Schultz, ed., Food for the World. Chicago: University of Chicago Press. pp.36-57.

OECD (1994). Trends in International Migration. Continous Reporting System on Migration Annual Report 1993. Paris: Organization for Economic Cooperation and Development.

OECD (2016). OECD Internationa/ Migration Database. Available at: https://stats.oecd.org/ Index.aspx?DataSetCode=MIG.

Panainte, S. (2013). Redobândirea cetățeniei române. O politică ce capătă viziune? [Reacquiring Romanian Citizenship. A policy that receives vision?]. București: Fundația pentru o Societate Deschisă. Available at: https://cetatenie.ro/.

Părean, M. (2012). Energy crisis in communist Romania. The Annales of the Univeristy of Oradea, pp.274-276.

Portes, A. and Böröcz, J. (1989). Contemporary Immigration: Theoretical Perspectives on Its Determinants and Modes of Incorporation. International Migration Review, 23(3), pp.606-630.

Reermann, O. (1997). Readmission Agreements. In: K. Hailbronner, D. A. Martin and H. Motomura, eds., Immigration admissions : the search for workable policies in Germany and the United States. Providence: Berghahn Books, pp.121-146.

Ronnås, P. (1984). Urbanization in Romania: A Geography of Social and Economic Change since Independence. Stockholm: Economic Research Institute, Stockholm School of Economics.

Rostow, W. (1960). The stages of economic growth. London: Cambridge University Press. Salt, J. (1989). A Comparative Overview of International Trends and Types, 1950-80. International Migration Review, 3, pp.444-445.

Sandu, D. (1984). Fluxuri de migrație în România [Migratory fluxes in Romania]. București: Editura Academiei RSR. 
Sandu, D. (2000a). Migrația circulatorie ca strategie de viață. [Circular migration as a life strategy]. Sociologie Româneascã, 2, pp.5-29.

Sandu, D. (2000b). Migrația transnațională a românilor din perspectiva unui recensamânt comunitar [The transnational migration of the Romanians from the perspective of a community census]. Sociologie Româneascã, 3-4, pp.5-50.

Sandu, D., ed. (2006). Locuirea temporară în străinătate. Migrația economică a românilor 1990-2006 [Living abroad. The economic migration of the Romanians between 19902006]. București: Fundația pentru o Societate Deschisă.

Sandu, D. (2010). Lumile sociale ale migrației românești în străinătate. [The social worlds of the Romanian migrants]. Iași: Polirom.

Sassen, S. [1988] (2006): Foreign investment: a neglected variable. In: Anthony M. and G. Lahav, eds., The migration reader. Exploring politics and policies. London: Lynne Rienner Publishers, pp.596-608

Sassen, S. (2005). The Global City: Introducing a Concept. Brown Journal of World Affairs, $11, \mathrm{pp} .27-44$.

Sik, E. (2006). Casual labour market on Moszkva ter - Narrowing immutability between 1995 and 2004. Közgazdasági Szemle, 53(3), pp.253-270.

Skeldon, R. (1997). Migration and development: A global perspective. Essex: Longman.

Skeldon R. (2012). Migration Transitions Revisited: Their Continued Relevance for the Development of Migration Theory. Population, Space and Place, 18(2), pp.154-166.

Sobotka, T. (2002). Ten years of rapid fertility changes in the European post-communist countries. Population Research Centre Working Paper Series, 02-01.

Stan, S. and Erne, R. (2013). Explaining Romanian labor migration: from development gaps to development trajectories. Labor History, 55(1), pp.21-46.

Szelényi I. (1996) Cities under socialism and after. In: G. Andrusz, M. Harloe and I. Szelényi, eds., Socialism: Urban and Regional Change and Conflict in Post-Socialist Societies. Cambridge Blackwell, pp.286-318.

Szőke, L. (1992). Hungarian Perspectives on Emigration and Immigration in the New European Architecture. International Migration Review, 26(2), pp.305-323.

Thornton, A. (2005). Reading History Sideways. The Fallacy and Enduring Impact of Developmental Paradigm. Chicago: Chicago University Press.

Thornton, A. (2013). Developmental Idealism, Demographic Change and Migration. Presentation at SEEMIG plenary, 22 May, Budapest.

Thornton, A., Dorius, S. and Swindle, J. (2015) Developmental Idealism: The Cultural Foundations of World Development Programs. Sociology of Development, 1, pp.277-320.

Thornton, A. and Philipov, D. (2009). Sweeping Changes in Marriage, Cohabitation and Childbearing in Central and Eastern Europe: New Insights from the Developmental Idealism Framework. European Journal of Population, 25(2), pp.123-156.

Todaro, M. P. (1969). A model of labor migration and urban unemployment in lessdeveloped countries. American Economic Review, 59, pp.138-148.

Todaro, M. P. and Maruszko, L. (1987). Illegal migration and US immigration reform: A conceptual framework. Population and Development Review, 13, pp.101-114. 
Tompea, A. D. and Năstuță, S. (2009). Romania. In: H. Fassmann, U. Reeger and W. Sievers, eds., Statistics and Reality Concepts and Measurements of Migration in Europe. Amsterdam: University Press Amsterdam, pp.217-233.

Trebici, V. (1978). Tranziția demografică în România. [The demographic transition in Romania]. Viitorul Social, 2, pp.335-344.

UNCHR (2001). Asylum Applications in Industrialized Countries 1980-1999. Geneva: United Nations High Commisioner for Refugees - Population Data Unit, Population and Geographical Data Section.

Verdery, K. (1991). National Ideology Under Socialism Identity and Cultural Politics in Ceausescu's Romania. Berkeley, Los Angeles, London: University of California Press.

Waterbury, M. (2014). Making Citizens Beyond the Border: Non-Resident Ethnic Citizenship in Post-Communist Europe. Problems of Post-Communism, 61, pp.36-49.

Wolff, L. (1994). Inventing Eastern Europe: the Map of Civilization in the Mind of Enlightenment. Stanford: Stanford University Press.

Xiao, C. (2010). Souls in exile: a study of Chinese migration workers in Romania. Beijing: ILO Office for China and Mongolia. Journal. Available at: http://www.lo.org/public/ libdoc/ilo/2010/110B09_189_engl.pdf.

Zelinsky, Z. (1971). The Hypothesis of the Mobility Transition. Geographical Review, 61, pp.219-249. 